OPEN ACCESS

Edited by: Junpei Zhou,

Yunnan Normal University, China

Reviewed by:

Ram Karan,

King Abdullah University of Science and Technology, Saudi Arabia

Hui Ni,

Jimei University, China

*Correspondence:

Satya P. Singh

satyapsingh@yahoo.com

Specialty section:

This article was submitted to

Extreme Microbiology,

a section of the journa

Frontiers in Microbiology

Received: 31 January 2020 Accepted: 20 April 2020

Published: 03 June 2020

Citation:

Bhatt HB and Singh SP (2020) Cloning, Expression, and Structural

Elucidation of a Biotechnologically

Potential Alkaline Serine Protease From a Newly Isolated Haloalkaliphilic

Bacillus lehensis JO-26.

Front. Microbiol. 11:941.

doi: 10.3389/fmicb.2020.00941

\section{Cloning, Expression, and Structural Elucidation of a Biotechnologically Potential Alkaline Serine Protease From a Newly Isolated Haloalkaliphilic Bacillus lehensis JO-26}

Hitarth B. Bhatt and Satya P. Singh*

UGC-CAS Department of Biosciences, Saurashtra University, Rajkot, India

An alkaline protease gene of Bacillus lehensis JO-26 from saline desert, Little Rann of Kutch, was cloned and expressed in Escherichia coli BL21 (DE3). A 1,014-bp ORF encoded 337 amino acids. The recombinant protease (APrBL) with Asp 97, His 127, and Ser 280 forming catalytic triad belongs to the subtilase S8 protease family. The gene was optimally expressed in soluble fraction with $0.2 \mathrm{mM}$ isopropyl $\beta$-D-thiogalactopyranoside (IPTG), $2 \%(\mathrm{w} / \mathrm{v}) \mathrm{NaCl}$ at $28^{\circ} \mathrm{C}$. APrBL, a monomer with a molecular mass of $34.6 \mathrm{kDa}$ was active over $\mathrm{pH} 8-11$ and $30^{\circ} \mathrm{C}-70^{\circ} \mathrm{C}$, optimally at $\mathrm{pH} 10$ and $50^{\circ} \mathrm{C}$. The enzyme was highly thermostable and retained $73 \%$ of the residual activity at $80^{\circ} \mathrm{C}$ up to $3 \mathrm{~h}$. It was significantly stimulated by sodium dodecyl sulfate (SDS), $\mathrm{Ca}^{2+}$, chloroform, toluene, n-butanol, and benzene while completely inhibited by phenylmethylsulfonyl fluoride (PMSF) and $\mathrm{Hg}^{2+}$. The serine nature of the protease was confirmed by its strong inhibition by PMSF. The APrBL gene was phylogenetically close to alkaline elastase YaB (P20724) and was distinct from the well-known commercial proteases subtilisin Carlsberg (CAB56500) and subtilisin BPN' (P00782). The structural elucidation revealed $31.75 \% \alpha$-helices, $22.55 \% \beta$-strands, and $45.70 \%$ coils. Although high glycine and fewer proline residues are a characteristic feature of the cold-adapted enzymes, the similar observation in thermally active APrBL suggests that this feature cannot be solely responsible for thermo/cold adaptation. The APrBL protease was highly effective as a detergent additive and in whey protein hydrolysis.

Keywords: recombinant alkaline protease, gene expression, Little Rann of Kutch, structure-function relationship, detergent additive, whey protein hydrolysis

\section{INTRODUCTION}

Proteases, being among the most important groups of the industrial enzymes, represent $60 \%$ of the total enzyme market (Jaouadi et al., 2008). The demand has increased due to its applications in various sectors such as detergent, leather, food, dairy, pharmaceutical, textile, and peptide synthesis (Haki and Rakshit, 2003; Jain et al., 2012; Purohit and Singh, 2013; Sinha and Khare, 2013; Raval et al., 2014). 
Majority of the industrial processes are carried out under the extreme conditions of temperature, $\mathrm{pH}$, and high concentrations of organic solvents, where majority of the enzymes fail to function. Therefore, enzymes of haloalkaliphile origin will serve the purpose of stability and activity at multiple of extremities (Raval et al., 2018). Proteases from halophilic microorganisms are in demand for various applications due to their ability to function at alkaline $\mathrm{pH}$, high temperatures, and high salt concentrations (Sinha and Khare, 2013; Raval et al., 2014). Thus, they are also suitable for food processing under saline conditions. Proteases are widely used in detergents due to inefficiency of non-enzymatic detergents for the removal of protein-containing materials from the textile fibers. The enzymes not only enhance the washing efficiency but also shorten the washing duration at moderate temperatures.

Whey contains approximately $20 \%$ of the total soluble milk proteins (Walstra and Jenness, 1984). In protein hydrolysis, peptide bonds are cleaved, resulting in peptides of different sizes and free amino acids. Protein hydrolysis is carried out either chemically or enzymatically. Chemical methods usually yield products with modified amino acids and reduced nutritional values. Therefore, the enzymatic hydrolysis is performed under moderate conditions without side reactions and loss of nutritional values (Tavano, 2013).

Bacillus strains are suitable sources of the commercial enzymes due to their ability to secrete enzymes in a short time (Maurer, 2004). As a matter of fact, different species of Bacillus genus are among the most common sources of commercial proteases (Contesini et al., 2018). Although many Bacillus strains produce alkaline proteases (Patel et al., 2006; Dodia et al., 2008; Jain et al., 2012; Raval et al., 2014), we need enzymes with better efficiency and features to perform under stressful conditions. Therefore, the search for suitable enzymes continues for various applications. Alkaline proteases are reported from bacteria and actinomycetes of different marine habitats (Thumar and Singh, 2009; Gohel and Singh, 2012, 2018; Annamalai et al., 2014; Raval et al., 2014, 2015; Thakrar and Singh, 2019; Sharma et al., 2020). However, only limited studies are available on the microorganisms of desert origin. The Little Rann of Kutch is a saline desert largely unexplored for its microbial diversity and biotechnological potential (Bhatt and Singh, 2016; Bhatt et al., 2017, 2018).

Further, a high level of production is desirable for the commercialization of any enzyme from microbial sources. In view of the investigations on the gene expression and costeffectiveness of the enzymes, the protease gene was cloned and expressed in mesophilic host, Escherichia coli. Only few reports exist on the gene cloning and characterization of the recombinant proteases of haloalkaliphilic microorganisms. Besides, sequence information of the protease gene will help in elucidating the structure-function relationship and identifying various functional regions of the encoded enzymes.

In consideration of the above scenario, we cloned an alkaline protease (APrBL) gene from a newly isolated haloalkaliphilic Bacillus lehensis and expressed into E. coli BL21 (DE3), a mesophilic host. The gene expression was optimized with respect to induction, growth temperature, and $\mathrm{NaCl}$ concentrations.
We purified and characterized the recombinant protease and assessed its potential as detergent additive and in whey protein hydrolysis. The study established the potential of this serine alkaline protease in detergent and food industries. This study represents the first account on the gene cloning, analysis of the expression, and characterization of a recombinant protease from a haloalkaliphilic bacterium of the saline desert, Little Rann of Kutch.

\section{MATERIALS AND METHODS}

\section{Bacterial Strains and Vectors}

A haloalkaliphilic bacterium B. lehensis JO-26 was isolated from the saline desert of Little Rann of Kutch (India). E. coli BL21 (DE3) (Merck Millipore, Germany) was used for the expression studies and was grown in LB supplemented with kanamycin $(50 \mu \mathrm{g} / \mathrm{ml})$ for the recombinant protein expression. pET28a (+) (Novagen, CA, United States) was used as an expression vector. Plasmid preparation and DNA purification were carried out using commercial kits (Qiagen, Germany). Restriction enzymes and other molecular biology reagents were from commercial sources (Roche, Germany).

\section{Genomic DNA Extraction, Primer Designing, and Gene Amplification}

Genomic DNA was extracted from $2 \mathrm{ml}$ of activated growth cultures (OD600 $\sim 0.8$ ) using the DNeasy Blood \& Tissue Kit for DNA (Qiagen, Germany). Isolated DNA was used as a template for the amplification of the alkaline protease (APrBL) gene. ORF finder tool of NCBI was used to identify the open reading frame of the APrBL gene. Based on the whole genome sequence of $B$. lehensis available in the NCBI database, a set of primer pair (APrBL NdeI $\mathrm{F}^{\prime}$ CCGCATATGGCGCAGGTTGGAACATTTTG and APrBL XhoI $\mathrm{R}^{\prime}$ CCGCTCGAGCGAGTAGGTCTCTTTTGCAG) was designed to obtain the APrBL gene without secretion signal. Restriction sites are underlined and highlighted in bold. Using APrBL F \& R primers, the APrBL gene was amplified using Emerald green master mix (Takara, Japan) under the optimized PCR program (denaturation step at $95^{\circ} \mathrm{C}$ for $5 \mathrm{~min}$, followed by 35 cycles of denaturation at $95^{\circ} \mathrm{C}$ for $50 \mathrm{~s}$, annealing at $56^{\circ} \mathrm{C}$ for $45 \mathrm{~s}$ and extension at $72^{\circ} \mathrm{C}$ for $1 \mathrm{~min} 30 \mathrm{~s}$ with final extension at $72^{\circ} \mathrm{C}$ for $7 \mathrm{~min}$ ) in $25-\mu \mathrm{l}$ reaction mixture using a thermocycler (Eppendorf, Germany).

\section{Construction of the Recombinant APrBL-pET28a}

A set of primers APrBL Forward and Reverse with NdeI and XhoI restriction sites was used to amplify the APrBL gene. The amplified product APrBL (200 ng) and expression vector pET28a $(2 \mu \mathrm{g})$ were digested with $\mathrm{NdeI}$ and $\mathrm{XhoI}$ restriction enzymes as per the manufacturer's instructions. The digested amplified product and vector were purified using the HiPurA PCR product purification kit (Himedia, India). Double-digested vector pET28a (+) (133 ng) and APrBL (88 ng) were ligated using T4 DNA ligase 
(Roche, Germany) at $16^{\circ} \mathrm{C}$ overnight. The ligated product was transformed into competent E. coli BL21 (DE3) cells. Colony PCR and double digestion of the plasmids with NdeI and XhoI were carried out to confirm the positive APrBL-pET28a clones.

\section{Gene Expression: Effect of Isopropyl $\beta$-D-Thiogalactopyranoside, Temperature, and Salt}

Seed culture of E. coli BL21 harboring APrBL-pET28a vector was prepared by growing cells on a rotary shaker $(200 \mathrm{rpm})$ for overnight at $37^{\circ} \mathrm{C}$. LB medium $(50 \mathrm{ml})$ containing kanamycin $(50 \mu \mathrm{g} / \mathrm{ml})$ was inoculated with $1 \%(\mathrm{v} / \mathrm{v})$ inoculum and incubated until optical density reaches to $0.5-0.6$ at $600 \mathrm{~nm}$. It was then followed by the addition of isopropyl $\beta$-D-thiogalactopyranoside (inducer, IPTG) and incubation for $20 \mathrm{~h}$ on a rotary shaker (200 rpm). Protease expression was examined at the IPTG concentrations of 0.2 and $1 \mathrm{mM}$ and at 28 and $37^{\circ} \mathrm{C}$ to optimize the distribution of the expressed protease in soluble fraction. The cells were harvested at 14,031 × g (Beckman Coulter Allegra 64R Centrifuge, United States) for $10 \mathrm{~min}$ at $4^{\circ} \mathrm{C}$, and the cell pellet was washed with buffer containing $50 \mathrm{mM} \mathrm{NaH}_{2} \mathrm{PO}_{4}$ and $100 \mathrm{mM} \mathrm{NaCl}$ ( $\mathrm{pH} \mathrm{8)}$. The cells were disrupted by sonication for $30 \mathrm{~s}$ in six cycles with Sartorius Labsonic $\mathrm{M}$ at $30 \mathrm{~Hz}$. Between each cycle, the samples were chilled in ice for $30 \mathrm{~s}$. The resulting supernatant was considered as soluble fraction. The pellets were treated with $8 \mathrm{M}$ urea for $30 \mathrm{~min}$ at $30^{\circ} \mathrm{C}$, followed by centrifugation at $9,744 \times g$ for $5 \mathrm{~min}$ at $4^{\circ} \mathrm{C}$ to obtain supernatant considered as the insoluble fraction (Purohit and Singh, 2013). Insoluble and soluble fractions of the induced and uninduced cells were analyzed by sodium dodecyl sulfate (SDS)-polyacrylamide gel electrophoresis (PAGE) on a $12 \%$ polyacrylamide gel. Similarly, the effect of $\mathrm{NaCl}$ concentrations $(0-4 \%, w / v)$ was examined on the expression of protease and its distribution in soluble fraction with other optimum conditions of $0.2 \mathrm{mM}$ IPTG and $28^{\circ} \mathrm{C}$ growth temperature. The expression was analyzed by plate diffusion assay and enzyme assay as described below.

\section{In silico Analysis of APrBL}

Nucleotide sequence of APrBL gene was used for phylogenetic analysis and was compared against NCBI database using BLASTn tool. Similarly, the protein sequence of APrBL was compared against the protein database using BLASTp tool. Multiple sequence alignment (MSA) was achieved using Clustal $\mathrm{W}$ software. The phylogenetic tree was constructed using the Neighbor-Joining method of MEGA 6 software (Tamura et al., 2013). Distances were calculated using the Kimura correction in a pairwise deletion manner (Kimura, 1980). The N-terminal signal peptide analysis was carried out by the SignalP version 5.0 program (Armenteros et al., 2019). The hydropathicity of the protein was determined using the Kyte and Doolittle scale (Kyte and Doolittle, 1982). Primary and secondary structure properties of the protease and amino acids were studied by Expasy and NCBI tools. Expasy's Protparam server ${ }^{1}$ was used

${ }^{1}$ http://web.expasy.org/protparam/ for detection of the physicochemical properties of these proteins. The number of amino acids, theoretical isoelectric point $(\mathrm{p} I)$, molecular weight, aliphatic index, instability index, grand average hydropathy (GRAVY), and total number of positive and negative residues were computed for each protein. Expasy's PROSITE tool $^{2}$ was used to determine the catalytic triad of the enzyme. The secondary structure configuration of APrBL was predicted by Endscript 2.0 (Gouet et al., 2003) and SOPMA tool (Geourjon and Deleage, 1995). Three-dimensional structure of the serine protease was modeled using the I-TASSER server for threedimensional (3D) structure prediction and validation (Yang et al., 2015). The model was also validated by structure assessment tool of SWISS-MODEL (Kiefer et al., 2009). Further, the hydropathy profile was plotted according to the method of Kyte and Doolittle using pscale tool (Kyte and Doolittle, 1982).

\section{Homology Modeling}

APrBL amino acid sequence without signal peptide was used for homology modeling. SWISS-MODEL Workspace server was used to identify the template and building protein model ${ }^{3}$ (Kiefer et al., 2009).

\section{Purification of the Recombinant Alkaline Protease}

The recombinant protease (APrBL) was purified under nondenaturing conditions using Novagen Ni-NTA His-Bind resin. The IPTG-induced recombinant E coli BL21 (DE3) cells were sonicated in binding buffer containing $50 \mathrm{mM}$ phosphate buffer ( $\mathrm{pH}$ 8), $100 \mathrm{mM} \mathrm{NaCl}, 10 \mathrm{mM} \mathrm{MgCl}_{2}, 1 \mathrm{mg} \mathrm{ml}^{1}$ lysozyme, $5 \mathrm{mM} \beta$-mercaptoethanol ( $\beta$-ME), and $5 \%(\mathrm{v} / \mathrm{v})$ glycerol. After sonication, debris was spun down and the supernatant containing APrBL was collected for purification. The chromatographic column was packed with Ni-NTA His.Bind Resin (Merck) and allowed to settle to generate $2 \mathrm{ml}$ of bed volume. The packed $\mathrm{Ni}$ NTA resin was washed with a 5-column volume of the deionized water to remove the ethanol. The column was then equilibrated with a 5-column volume of the binding buffer. Thereafter, the supernatant was passed through the column several times for binding of the $6 \times$ histidine-containing recombinant protein to the Ni-NTA resin. After binding, 2-column volume of wash buffer (binding buffer $+20 \mathrm{mM}$ imidazole) was passed through the column in order to wash out non-specific proteins and other impurities. The recombinant protein was eluted with one column volume of the elution buffer (binding buffer + imidazole) with $250 \mathrm{mM}$ and $500 \mathrm{mM}$ of imidazole in increasing gradient, and fractions were collected. The fractions were examined for purity of the enzyme on $12 \%$ SDS-PAGE. The protease activity of the purified APrBL was confirmed by enzyme assay.

\section{Protease Assay and Protein Estimation}

The protease activity was measured by Anson-Hagihara's method using tyrosine as standard $(0-100 \mathrm{~g} / \mathrm{ml})$ (Hagihara, 1958). The enzyme ( $0.5 \mathrm{ml}$ appropriately diluted enzyme) was added to $3.0 \mathrm{ml}$ casein $[0.6 \%(\mathrm{w} / \mathrm{v})$ in $20 \mathrm{mM} \mathrm{NaOH}-$ Borax buffer, $\mathrm{pH} 10]$,

\footnotetext{
${ }^{2}$ https://prosite.expasy.org/

${ }^{3} \mathrm{http} / / /$ swissmodel.expasy.org/workspace
} 
and the reaction mixture was incubated at $50^{\circ} \mathrm{C}$ for $10 \mathrm{~min}$. The reaction was terminated by the addition of $3.2 \mathrm{ml}$ of TCA mixture $(0.11 \mathrm{M}$ trichloro acetic acid, $0.22 \mathrm{M}$ sodium acetate, and $0.33 \mathrm{M}$ acetic acid) and incubated at room temperature for $30 \mathrm{~min}$. The precipitates were removed by filtration through Whatman-1 filter paper, and the absorbance of the filtrate was measured at $280 \mathrm{~nm}$. One unit of alkaline protease activity was defined as the amount of enzyme liberating $1 \mu \mathrm{g}$ of tyrosine per minute under the assay conditions. Protein concentrations were determined by the method of Bradford (1976) using bovine serum albumin as a standard.

\section{Kinetic Parameters of APrBL}

$V_{\max }$ and $K_{\mathrm{m}}$ were determined using Lineweaver-Burk double reciprocal $(1 / \mathrm{V}$ versus $1 / \mathrm{S})$ plot by measuring the activity at various concentrations of casein substrate $(0.25-10 \mathrm{mg} / \mathrm{ml})$ under the standard conditions. The value of the turnover number $\left(\mathrm{K}_{\mathrm{cat}}\right)$ was calculated using the following equation:

$$
K_{\mathrm{cat}}=\frac{V_{\mathrm{max}}}{[E t]}
$$

where $[E]$ refers to the active enzyme concentration, $V_{\max }$ refers to the maximum reaction rate, and $K_{\text {cat }}$ is defined as the maximum number of chemical conversions of substrate molecules per second that a single catalytic site will execute for a given enzyme concentration (Mechri et al., 2017). For the determination of $K_{\text {cat }}$ and $K_{\text {cat }} / K_{\mathrm{m}}$, the value of $V_{\max }$ was expressed in terms of $\mu \mathrm{moles} / \mathrm{ml} / \mathrm{min}$.

\section{Enzyme Secretion by Plate Diffusion Assay}

The soluble fractions of the expressed enzyme were analyzed for the enzyme activity using plate diffusion assay. The enzyme preparations were dispensed into wells created in the gelatin agar plate $(3 \%$ Agar $+1 \%$ gelatin in $50 \mathrm{mM}$ glycine- $\mathrm{NaOH}$ buffer, $\mathrm{pH}$ 10). The plates were then incubated for $24 \mathrm{~h}$ at $50^{\circ} \mathrm{C}$ followed by the observation of the zone of gelatin hydrolysis around the wells.

\section{Biochemical Characterization of APrBL Effect of Temperature and $\mathrm{pH}$ on the Activity and Stability of the Enzyme}

The temperature profile of the enzyme was determined using standard assay at varying temperatures in the range of 30$80^{\circ} \mathrm{C}$. For thermal stability, the enzyme was preincubated for $30 \mathrm{~min}$ at the temperatures in the range of $40-80^{\circ} \mathrm{C}$. Aliquots were withdrawn at 1,3 , and $24 \mathrm{~h}$, and the protease activity was determined. The residual activities were determined by taking the activity prior to incubation as $100 \%$. The assay was performed in $20 \mathrm{mM}$ borax- $\mathrm{NaOH}$ buffer ( $\mathrm{pH} 10$ ) using $0.6 \%$ $(\mathrm{w} / \mathrm{v})$ casein as a substrate.

The effect of $\mathrm{pH}$ on the enzyme activity was determined in buffers of different $\mathrm{pH}$. To determine the optimum $\mathrm{pH}$, sodium phosphate buffer ( $\mathrm{pH} 7.0$ ), Tris-HCl buffer ( $\mathrm{pH}$ 8-9), borax$\mathrm{NaOH}$ buffer ( $\mathrm{pH} 10$ ), and glycine-NaOH buffer $(\mathrm{pH} 11-12$ ) were used. The $\mathrm{pH}$ stability was determined by preincubating the enzyme at $\mathrm{pH} 8-12$. Aliquots were withdrawn at 1,3 , and $24 \mathrm{~h}$, and the protease activities were determined.

\section{Effect of Metal lons on the Enzyme Activity}

The effect of various metal ions on APrBL activity was assessed by preincubating the enzyme with $5 \mathrm{mM}$ concentration of different metal ions: $\mathrm{CaCl}_{2}, \mathrm{MgSO}_{4}, \mathrm{HgCl}_{2}, \mathrm{CoCl}_{2}, \mathrm{MnCl}_{2}, \mathrm{FeSO}_{4}$, and $\mathrm{ZnCl}_{2}$ for $30 \mathrm{~min}$. The residual activities were measured using casein as substrate at $\mathrm{pH} 10$ and $50^{\circ} \mathrm{C}$. The activity measured without metal ions was considered as $100 \%$.

\section{Effect of Solvents on the Enzyme Activity}

The effect of organic solvents on APrBL activity was examined by preincubating the enzyme with $10 \%(\mathrm{v} / \mathrm{v})$ of $\mathrm{n}$-hexane, $\mathrm{n}$-butanol, iso-propanol, ethanol, methanol, chloroform, glycerol, benzene, and toluene for $1 \mathrm{~h}$. The residual activities were measured using casein as substrate at $\mathrm{pH} 10$ and $50^{\circ} \mathrm{C}$. For the control, the organic solvent was replaced with an equivalent amount of borax- $\mathrm{NaOH}$ buffer $(20 \mathrm{mM}, \mathrm{pH} 10)$. The relative activities were calculated taking the activity of the control as $100 \%$.

\section{Effect of Inhibitors and Surfactants on Enzyme Activity}

To evaluate the effects of inhibitors and surfactants on the enzyme activity, APrBL was preincubated with $5 \mathrm{mM}$ of different inhibitors such as ethylenediaminetetraacetic acid (EDTA), $\beta$-ME, phenylmethylsulfonyl fluoride (PMSF), dithiothreitol (DTT), and 1\% (w/v) of surfactants such as SDS, Triton X-100, and Tween 80 for $30 \mathrm{~min}$ at room temperature before the residual activities were measured. The activity without any additive was considered as $100 \%$.

\section{Applications of the Recombinant Alkaline Protease APrBL Detergent Additive: Wash Performance Analysis}

Application of the recombinant alkaline protease APrBL was assessed as detergent additive by wash performance analysis. New cotton cloth pieces $(6 \mathrm{~cm} \times 6 \mathrm{~cm})$ were stained with human blood $(0.5 \mathrm{ml})$. Five different commercial detergents Ariel, Tide, Surf, Nirma, and Wheel were used at the concentration of $7 \mathrm{mg} / \mathrm{ml}$ to simulate washing conditions. Endogenous protease present in these detergents was inactivated by incubating the solid detergents at $70^{\circ} \mathrm{C}$ for $1 \mathrm{~h}$ prior to the addition of APrBL enzyme. The following sets were prepared:

1. Flask with tap water $(25 \mathrm{ml})$.

2. Five flask with tap water $(25 \mathrm{ml})+$ Each different detergent.

3. Five flask with tap water $(25 \mathrm{ml})+$ Each different boiled detergent + APrBL (200 U).

4. Flask with tap water $(25 \mathrm{ml})+\mathrm{APrBL}(200 \mathrm{U})$.

Then, the stained cloth pieces were shake-incubated (100 rpm) in abovementioned flasks with different wash conditions at $40^{\circ} \mathrm{C}$ for 10 min containing a total volume of $25 \mathrm{ml}$ of tap water. After incubation, cloth pieces were taken out, rinsed with water, and dried. Untreated stained cloth pieces and treated with only tap water were taken as control. The performance 
of the recombinant alkaline protease in bloodstain removal was evaluated by visual examination.

\section{Whey Protein Hydrolysis}

Whey solution was adjusted to $\mathrm{pH} 10$ with $3 \mathrm{M} \mathrm{NaOH}$ solution. APrBL at $300 \mathrm{U}$ was added into the whey solutions. Two negative controls were included to compare the effect of APrBL for whey protein hydrolysis. In one control, enzyme was replaced with equal amounts of borax- $\mathrm{NaOH}$ buffer (20 mM, pH 10), while in another control, denatured alkaline protease APrBL was added. The reaction mixture was incubated for $8 \mathrm{~h}$ at $45^{\circ} \mathrm{C}$ with continuous shaking. The aliquots were withdrawn at regular time intervals, and hydrolysis reactions were terminated by heating at $90^{\circ} \mathrm{C}$ for $15 \mathrm{~min}$ in water bath (Shu et al., 2018). Total protein content of these sets was determined before and after hydrolysis using Bradford's method (Bradford, 1976).

Degree of hydrolysis (DH) was calculated using soluble protein content method (Morais et al., 2013; Sinha and Khare, 2015). One milliliter of $10 \%$ (w/v) trichloroacetic acid was added to $1 \mathrm{ml}$ of the aliquot collected after enzymatic hydrolysis and incubated at $37^{\circ} \mathrm{C}$ for $30 \mathrm{~min}$. The mixture was then centrifuged at $10,000 \mathrm{rpm}$ for $10 \mathrm{~min}$ at room temperature, and the total content of the soluble protein was determined by Bradford's method (Bradford, 1976). The DH was calculated as follows:

Degree of Hydrolysis (\%)

$$
=\frac{\text { Soluble protein content in } 10 \% \mathrm{TCA}(\mathrm{mg}) \times 100}{\text { Total protein content }(\mathrm{mg})}
$$

\section{RESULTS AND DISCUSSION}

\section{Gene Amplification, Sequencing, and Phylogenetic Analysis}

The APrBL gene without the signal sequence was amplified using primer pair (APrBL NdeI F/XhoI R), designed based on whole genome sequence of $B$. lehensis G1 (CP003923) available in NCBI database. Signal peptides usually have no role except the export of protein in the periplasmic space. Therefore, production of recombinant protein without signal peptide in $E$. coli would not alter its biochemical characteristics and function. Moreover, removal of signal peptide has been reported to increase the expression of recombinant protein (Gopal and Kumar, 2013). Some reports describe the expression of proteases without signal peptide (Joshi and Satyanarayana, 2013; Cheng et al., 2015; Devi et al., 2016).

The APrBL gene coding full-length ORF of 1,014 bp with a start and stop codon consisted of 337 amino acid residues: a pro-peptide of 71 and a mature protein of 266 amino acids. The molecular mass was $34.5 \mathrm{kDa}$, and isoelectric point (pI) was 4.66. The corresponding molecular weights with propeptide regions are reported earlier (Jaouadi et al., 2008; Deng et al., 2011; Cheng et al., 2015; Zhang et al., 2016). PROSITE analysis of the ORF revealed the catalytic triads of APrBL to be Asp 97, His 127, and Ser 280, a common feature of the serine proteases of subtilase superfamily (Siezen and Leunissen, 1997; Purohit and Singh, 2014).
BLASTn analysis of the cloned gene revealed 98.2\% similarity with the alkaline protease of B. lehensis G1 (CP003923), 97.9\% with $\mathrm{YaB}$ alkaline elastase subtilisin gene of Bacillus subtilis (M28537), and 95.4\% with AprN alkaline protease of Bacillus sp. (AB005792). Whereas the BLASTp analysis revealed highest sequence similarity of $99.3 \%$ with both alkaline protease of B. lehensis MLB2 (AFK08970) and alkaline elastase YaB of Bacillus sp. YaB (P20724) followed by 97.8\% with AprN alkaline protease of Bacillus sp. (BAA25184). Further, APrBL has shown 82.3 and $80.4 \%$ similarity with the subtilisin savinase of Bacillus sp. (P29600) and alkaline protease of Bacillus clausii KSM-K16 (Q99405), respectively. The APrBL protease was further compared with other proteases with respect to amino acid composition, structural features, and phylogenetic analysis. APrBL closely related to alkaline elastase YaB of Bacillus sp. YaB and alkaline protease BLAP of $B$. lehensis MLB2 (AFK08970). On the other hand, it distantly related to subtilisin Carlsberg (CAB56500) of Bacillus licheniformis and subtilisin BPN'(P00782) from Bacillus amyloliquefaciens (Figure 1 and Table 1). The alkaline protease gene sequence of B. lehensis JO-26 (APrBL) has been submitted to GenBank (Accession No. MN104891).

\section{Expression of the Alkaline Protease Gene in Escherichia coli Effect of Isopropyl $\beta$-D-Thiogalactopyranoside and Temperature on Gene Expression}

It is highly desirable to get the expressed protein in soluble fraction due to its easy recovery, cost-effective purification, and minimum activity loss and time consumption (Sørensen and Mortensen, 2005). Among the strategies to limit trapping of the expressed proteins in insoluble fraction and thus reducing the formation of the inclusion bodies, growth of the host organism at low temperatures with lower induction level are important (Sørensen and Mortensen, 2005; Rosano and Ceccarelli, 2014). In the present report, the growth of the host was carried out at various temperatures and different levels of induction. At $37^{\circ} \mathrm{C}$, while growth of the organisms was highest, the expressed protease was largely trapped into the inclusion bodies, i.e., in insoluble fraction. On the contrary, growth at $28^{\circ} \mathrm{C}$ enhanced the solubility of the expressed protein despite lower growth of the host. There are several reports on the expression of alkaline protease in soluble fraction at lower temperatures of $27-30^{\circ} \mathrm{C}$ (Gohel and Singh, 2012; Joshi and Satyanarayana, 2013; Purohit and Singh, 2014; Devi et al., 2016).

The synergistic effect of IPTG induction and growth temperatures on APrBL expression was reflected by the fact that despite reduced growth of the recombinant E. coli at $1 \mathrm{mM}$ IPTG, the expression level was quite comparable at both $0.2 \mathrm{mM}$ and $1 \mathrm{mM}$ IPTG concentrations at both $28^{\circ} \mathrm{C}$ and $37^{\circ} \mathrm{C}$ temperatures (Figure 2A).

Although expression was higher at $1 \mathrm{mM}$ IPTG induction, considering the correlation of the growth and expression level, IPTG induction at $0.2 \mathrm{mM}$ can be considered optimum for the APrBL expression. Similarly, a study on the expression of cellobiose phosphorylase from cellvibrio gilvus revealed that 


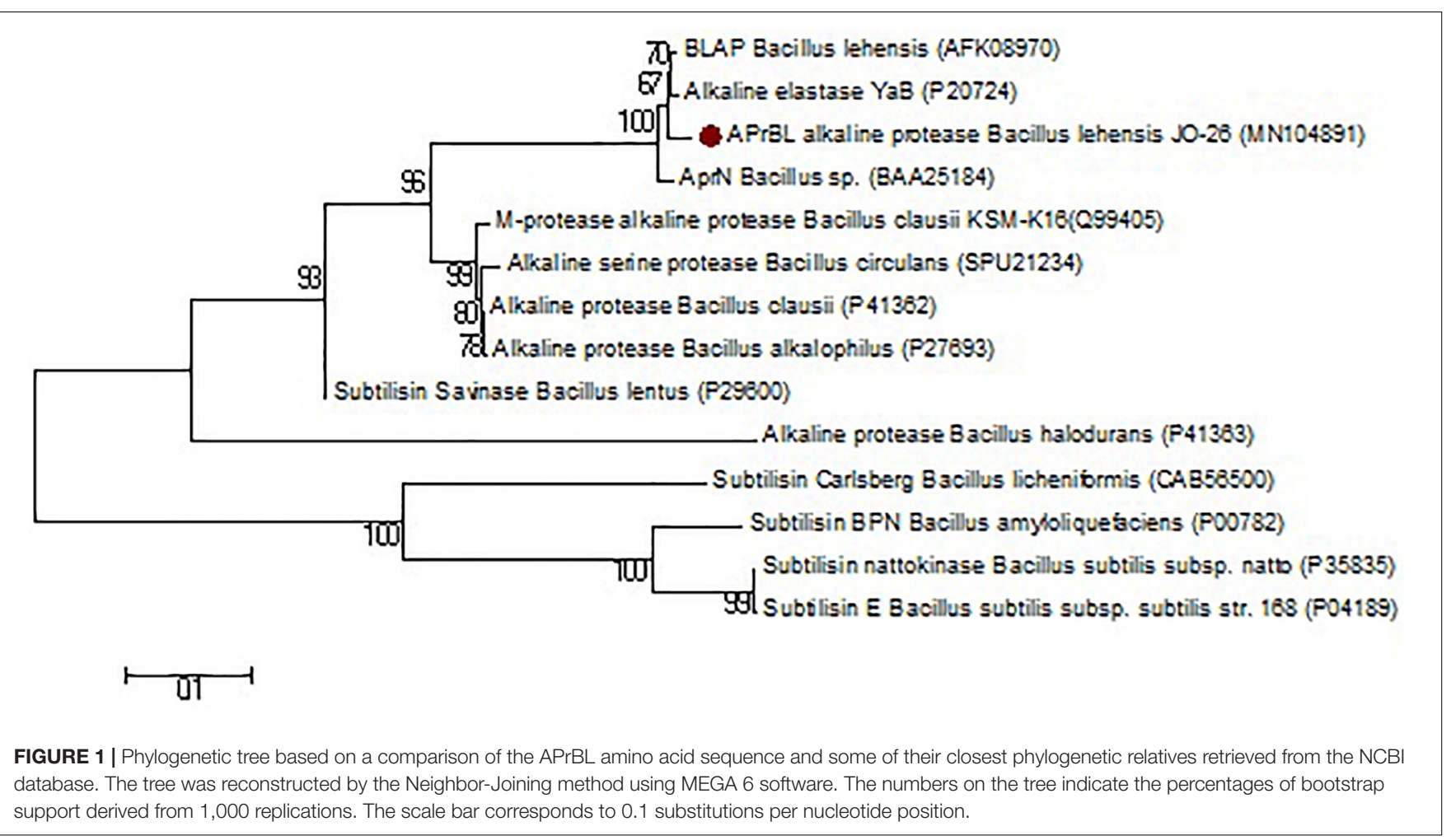

TABLE 1 | Comparison of primary structure profile of APrBL with other reported proteases including phylogenetic neighbors.

\begin{tabular}{|c|c|c|c|c|c|c|c|}
\hline Enzymes & Hydrophobic aa (\%) & Aromatic aa (\%) & Asp + Glu/Arg + Lys & Theoritical PI & Gravy index & Instability index & Aliphatic index \\
\hline YaB (P20724) & 56 & 7.2 & 1.84 & 4.66 & 0.014 & 26.01 & 87.54 \\
\hline AprN (BAA25184) & 55.5 & 7.3 & 1.78 & 4.77 & -0.002 & 26.28 & 87.28 \\
\hline BLAP (AFK08970) & 56 & 7.5 & 1.84 & 4.72 & 0.025 & 26.08 & 87.54 \\
\hline Subtilisin BPN' (NC_014551) & 52.6 & 8.6 & 0.89 & 8.73 & -0.105 & 26.29 & 78.51 \\
\hline
\end{tabular}

enzyme activity was higher in soluble fraction when cells were grown at $25^{\circ} \mathrm{C}$ as compared with $37^{\circ} \mathrm{C}$ (Singh et al., 2010). Furthermore, the enzyme activity was higher in soluble fraction at $0.1 \mathrm{mM}$ IPTG induction as compared to $1 \mathrm{mM}$ IPTG (Singh et al., 2010).

\section{Effect of Salt Concentration}

There is scarce information on the effect of salt on the gene expression in E. coli. The main reason to study the effect of salt on the expression of APrBL protease gene was the haloalkaliphilic nature of the native strain B. lehensis JO-26. The maximum expression was achieved with $2 \% \mathrm{NaCl}(\mathrm{w} / \mathrm{v})$. Growth of $E$. coli along with protease expression increased up to $1 \% \mathrm{NaCl}(\mathrm{w} / \mathrm{v})$ (Figure 3). Despite reduced growth, the enzyme production was higher at $2 \% \mathrm{NaCl}(\mathrm{w} / \mathrm{v})$ concentration. At $4 \% \mathrm{NaCl}(\mathrm{w} / \mathrm{v})$ concentration, both growth of the host and protease production decreased. The data clearly suggested that with increasing salt concentration, expression of functional recombinant APrBL increased up to $2 \% \mathrm{NaCl}$ (w/v) (Figure 3 and Supplementary Figure S1).

\section{Purification of the Recombinant Protease}

The recombinant protease appeared to be located in the cytoplasmic space as extracellular fraction did not contain any protease activity. The maximum expressed enzyme in soluble fraction was observed at $0.2 \mathrm{mM}$ IPTG induction after $20 \mathrm{~h}$ of growth at $28^{\circ} \mathrm{C}$ and $200 \mathrm{rpm}$ agitation. The soluble fraction of APrBL was purified onto Ni-NTA matrix using $250 \mathrm{mM}$ imidazole for elution. The purified APrBL resolved as a single band of $34.6 \pm 1.0 \mathrm{kDa}$ on SDS-PAGE (Figure 2B). The purified recombinant enzyme exhibited a 16.93-fold increase in the specific activity with a yield of $84.6 \%$ (Table 2). The molecular masses of microbial alkaline proteases with some exceptions range between 15 and $40 \mathrm{kDa}$ (Dodia et al., 2008; Haddar et al., 2009; Sinha and Khare, 2013; Raval et al., 2014). Alkaline proteases of similar molecular mass to APrBL have been cloned into mesophilic hosts, such as $34 \mathrm{kDa}$ from Bacillus pumilus CBS (Jaouadi et al., 2008), $34.4 \mathrm{kDa}$ from Bacillus vallismortis (Cheng et al., 2015), and $35.6 \mathrm{kDa}$ from Planococcus sp. (Zhang et al., 2016). Zone of the utilization of the substrate was observed in the plate diffusion assay of 

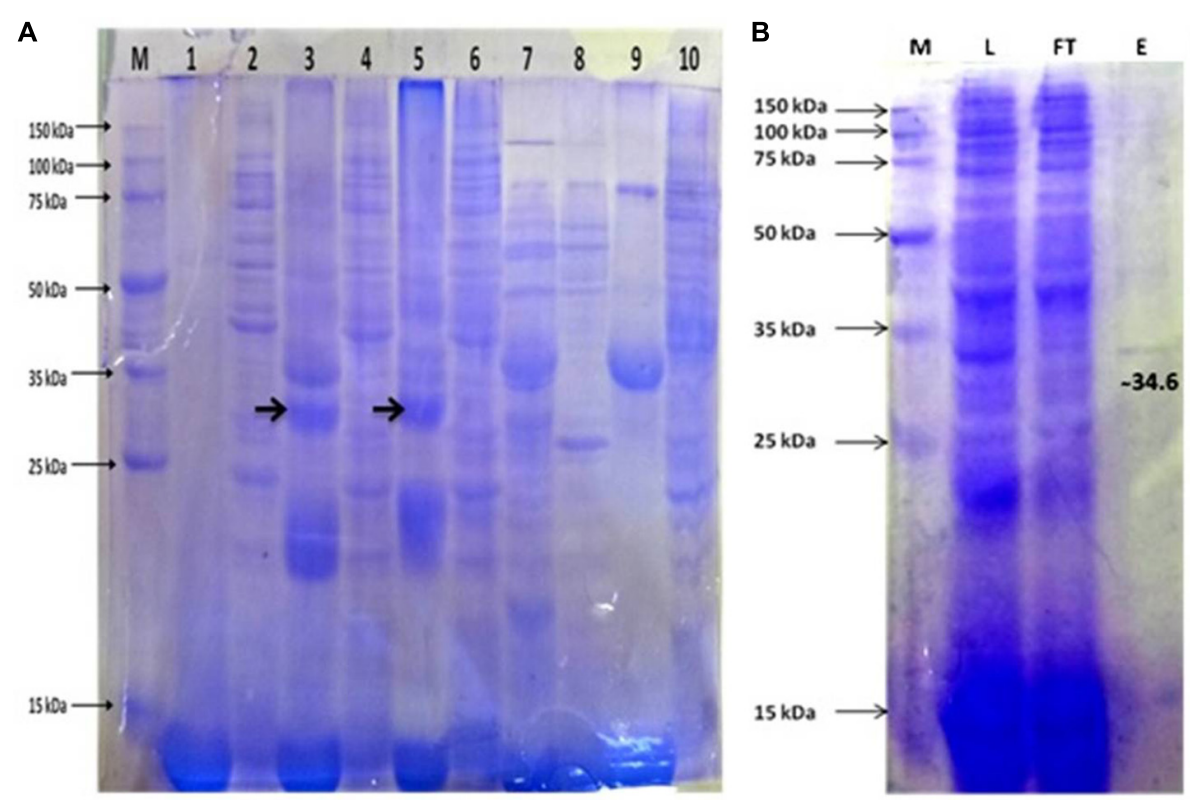

FIGURE 2 | (A) Protein expression profile of APrBL. M: 15-150 KD, Lane 1: Preinduced soluble fraction of Escherichia coli BL21 (DE3) harboring recombinant APrBL-pET28a, Lane 2: Preinduced insoluble fraction of E. coli BL21 (DE3) harboring recombinant APrBL-pET28a, Lane 3: Soluble fraction of E. coli BL21 (DE3) harboring recombinant APrBL-pET28a induced with $0.2 \mathrm{mM} \mathrm{IPTG,} \mathrm{Lane} \mathrm{4:} \mathrm{Insoluble} \mathrm{fraction} \mathrm{of} \mathrm{E.} \mathrm{coli} \mathrm{BL21} \mathrm{(DE3)} \mathrm{harboring} \mathrm{recombinant} \mathrm{APrBL-pET28a} \mathrm{induced}$ with 0.2 mM IPTG, Lane 5: Soluble fraction of E. coli BL21 (DE3) harboring recombinant APrBL-pET28a induced with 1 mM IPTG, Lane 6: Insoluble fraction of E. coli BL21 (DE3) harboring recombinant APrBL-pET28a induced with $1 \mathrm{mM} \mathrm{IPTG,} \mathrm{Lane} \mathrm{7:} \mathrm{Soluble} \mathrm{fraction} \mathrm{of} \mathrm{E.} \mathrm{coli} \mathrm{BL21} \mathrm{(DE3),} \mathrm{Lane} \mathrm{8:} \mathrm{Insoluble} \mathrm{fraction} \mathrm{of} \mathrm{E.} \mathrm{coli} \mathrm{BL21}$ (DE3), Lane 9: Uninduced soluble fraction of $E$. coli BL21 (DE3) harboring recombinant APrBL-pET28a, Lane 10: Uninduced insoluble fraction of $E$. coli BL21 (DE3) harboring recombinant APrBL-pET28a. (B) Protein purification using Ni-NTA column after expression of the protein in pET28a, 28 $8^{\circ} \mathrm{C}, 0.2 \mathrm{mM} I P T G$. M: $15-150 \mathrm{KD}$, L: Soluble fraction of E. coli BL21 (DE3) harboring recombinant APrBL-pET28a induced with 0.2 mM IPTG, FT: Flow through from the column, E: Column elution in $250 \mathrm{mM}$ imidazole.

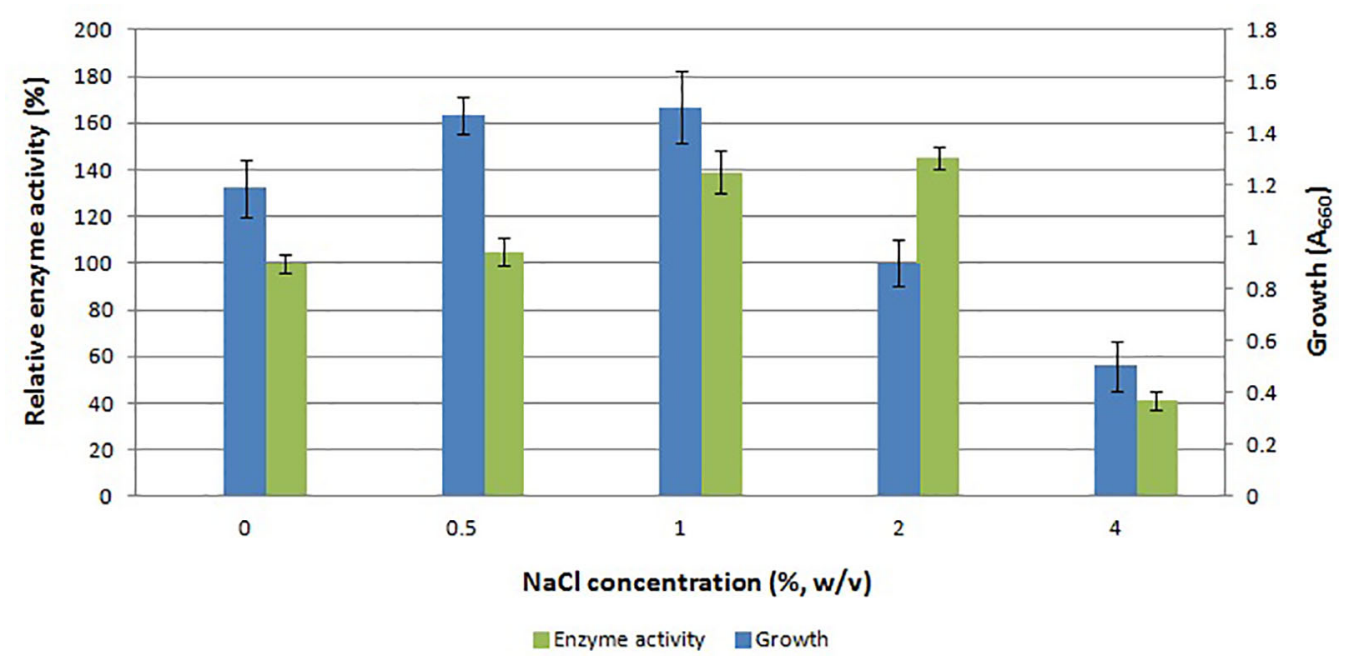

FIGURE 3 | Effect of $\mathrm{NaCl}$ concentration on growth and APrBL activity.

the purified APrBL, confirming the activity of the enzyme (Supplementary Figure S2).

\section{Kinetic Parameters: $K_{\mathrm{m}}, V_{\max }$, and $K_{\text {cat }}$}

$K_{\mathrm{m}}$ and $V_{\max }$ were computed as $1.38 \mathrm{mg} / \mathrm{ml}$ and $27.14 \mu \mathrm{mol}$ $\mathrm{mg}^{-1} \mathrm{~min}^{-1}(212.76 \mathrm{U} / \mathrm{ml})$, respectively. The $K_{\mathrm{m}}$ is inversely proportional to the enzyme's affinity with the substrate. The APrBL protease has low $K_{\mathrm{m}}$ value compared to other reported proteases from Bacillus sp. (1.53-2.5 mg/ml), metagenomic alkaline protease $(1.70 \mathrm{mg} / \mathrm{ml})$, Bacillus halotolerance (10 mg/ml), Bacillus marismortui $(2.5 \mathrm{mg} / \mathrm{ml})$, Shewanella arctica (1.75 mg/ml), Idiomarina sp. (3.76 mg/ml) (Patel et al., 2006; 
TABLE 2 | Purification of the recombinant alkaline protease APrBL by Ni-NTA affinity chromatography.

\begin{tabular}{lccccc}
\hline $\begin{array}{l}\text { Enzyme } \\
\text { preparation }\end{array}$ & $\begin{array}{c}\text { Total } \\
\text { activity } \\
(\mathbf{U})\end{array}$ & $\begin{array}{c}\text { Total } \\
\text { protein } \\
\text { (mg) }\end{array}$ & $\begin{array}{c}\text { Specific } \\
\text { activity } \\
\mathbf{( U / m g )}\end{array}$ & $\begin{array}{c}\text { Purification } \\
\text { fold }\end{array}$ & $\begin{array}{c}\text { Yield } \\
\text { (\%) }\end{array}$ \\
\hline $\begin{array}{l}\text { Recombinant crude } \\
\text { fraction }\end{array}$ & 1,392 & 4.8 & 290 & 1 & 100 \\
$\begin{array}{l}\text { Ni-NTA affinity } \\
\text { Chromatography }\end{array}$ & 1,179 & 0.24 & 4,912 & 16.93 & 84.6 \\
\begin{tabular}{l} 
Purified fraction \\
\hline
\end{tabular} & & & & & \\
\hline
\end{tabular}

Dodia et al., 2008; Sinha and Khare, 2013; Qoura et al., 2015; Devi et al., 2016; Dorra et al., 2018; Zhou et al., 2018). $V_{\max }$ is the catalytic activity of an enzyme usually desired as high as possible. The studied enzyme had higher $V_{\max }$ than other reported proteases from B. vallismortis (49.8 $\mu \mathrm{g} \mathrm{ml}^{-1} \mathrm{~min}^{-1}$ ), Bacillus circulans $(1.8 \mu \mathrm{mol} / \mathrm{min}), B$. lehensis $\left(25 \mathrm{nmol} \mathrm{mg} \mathrm{mg}^{-1}\right.$ ), and metagenomic protease $(278.2 \mathrm{U} / \mathrm{mg} / \mathrm{min}$ ) (Joshi and Satyanarayana, 2013; Cheng et al., 2015; Devi et al., 2016; Patil et al., 2016). The results signify high affinity and catalytic efficiency of APrBL compared to other proteases.

$K_{\text {cat }}$ is the maximum number of conversions of the substrate molecules per second by a single catalytic site at a given enzyme concentration (Mechri et al., 2017). $K_{\text {cat }}$ is a constant independent of the amount of the enzyme. With respect to the present enzyme, the catalytic constant $K_{\text {cat }}$ was deduced as $0.549 \mathrm{~S}^{-1}$. In comparison, Cheng et al. (2015) reported a $K_{\text {cat }}$ value of $4.35 \mathrm{~min}^{-1}$ for an alkaline protease from B. vallismortis. $K_{\text {cat }}$ values of $0.13 \mathrm{~S}^{-1}$ and $3.99 \times 10^{-2} \mathrm{~S}^{-1}$ were reported for the alkaline proteases of Bacillus sp. and Bacillus pseudofirmus, respectively (Sinha and Khare, 2013; Raval et al., 2014). However, a higher $K_{\text {cat }}$ value of $289 \mathrm{~S}^{-1}$ has also been earlier reported with low $V_{\text {max }}$ (Joshi and Satyanarayana, 2013). Overall, the kinetic parameters; $K_{\mathrm{m}}, V_{\mathrm{max}}$, and $K_{\text {cat }}$ of the APrBL suggest its potential and suitability as a biocatalyst in comparison to the previously reported alkaline proteases.

\section{Characterization of Recombinant Protease \\ Effect of $\mathrm{pH}$ on the Enzyme Activity and Stability}

The APrBL was active in a broad range of $\mathrm{pH} \mathrm{8-12}$ with an optimum at $\mathrm{pH} 10$, thus confirming the alkaline nature of the enzyme (Figure 4B). The trend of the $\mathrm{pH}$ optima is consistent with the proteases of Bacillus sp. (Patel et al., 2006), B. pumilus (Jaouadi et al., 2008), haloalkaliphilic bacterium strain AH-6 (Dodia et al., 2008), Nocardiopsis alba (Gohel and Singh, 2012), Bacillus sp. (Jain et al., 2012), and B. pseudofirmus (Raval et al., 2014). The trends, however, vary from the $\mathrm{pH}$ optima of the alkaline proteases of $B$. vallismortis (optimum $\mathrm{pH}, 6.5$ ) (Cheng et al., 2015), Bacillus mojavensis (optimum $\mathrm{pH}, 8.5$ ) (Haddar et al., 2009), Bacillus halotolerans (optimum pH, 9) (Dorra et al., 2018), Bacillus sp. (optimum pH, 9) (Sinha and Khare, 2013), and Bacillus sp. (optimum pH, 9) (Briki et al., 2016).

The recombinant protease $\mathrm{APrBL}$ was highly stable in the range of $\mathrm{pH}$ 8-12 (Figure 4D). The enzyme was stable at $\mathrm{pH} 8-12$, for $3 \mathrm{~h}$, with significant stability displayed even after prolonged incubation up to $24 \mathrm{~h}$ at $\mathrm{pH} 9-10$. The enzyme retained more than $80 \%$ of the residual activity at $\mathrm{pH} 9$ and 10 , while it retained $50-60 \%$ activity at $\mathrm{pH}$. The trends, however, differ from the alkaline protease of $B$. vallismortis which was stable at $\mathrm{pH}$ 5.6-9.6 (Cheng et al., 2015). Effective functioning of the protease over a broad $\mathrm{pH}$ range is an important criterion for the application as detergent additives. The APrBL protease fulfills this condition as it was active and stable in the $\mathrm{pH}$ range of 8-12. The APrBL appears more efficient at alkaline $\mathrm{pH}$ as compared to the commercial detergent enzyme Alcalase (Novozymes A/S) produced by $B$. licheniformis, having a maximal activity at $\mathrm{pH}$ 8-9 (Van Kampen and Merget, 2002). The enzymatic features are quite comparable with Purafect (Genencor International Inc., United States), a genetically engineered donor B. lentus expressed in Bacillus sp. having the optimum activity at $\mathrm{pH} 10$ (Van Kampen and Merget, 2002) and Maxatase (Gist-Brocades), produced by $B$. licheniformis with a maximum activity at $\mathrm{pH} 9-10$ (Beg and Gupta, 2003).

\section{Effect of Temperature on the Activity and Stability}

The enzyme was active at temperatures $30-70^{\circ} \mathrm{C}$ with optimum activity at $50^{\circ} \mathrm{C}$ (Figure $4 \mathrm{~A}$ ). The enzyme retained $76 \%$ of the residual activity at $60^{\circ} \mathrm{C}$, whereas at $40^{\circ} \mathrm{C}, 37 \%$ of the activity was evident. A sharp increase in the activity was observed from 40 to $50^{\circ} \mathrm{C}$, while the activity decreased from 50 to $60^{\circ} \mathrm{C}$, clearly suggesting the thermally active nature of the enzyme. These results, however, deviate from the alkaline proteases of Planococcus sp. (optima at $35^{\circ} \mathrm{C}$ ) and Bacillus sp. (optima at $37^{\circ} \mathrm{C}$ ) (Briki et al., 2016; Zhang et al., 2016). Interestingly, the enzyme also differs from its phylogenetic relative, BLAP alkaline protease, of the same species B. lehensis (Joshi and Satyanarayana, 2013). Despite sharing a common temperature optima of $50^{\circ} \mathrm{C}$, while BLAP rapidly loses activity at $60^{\circ} \mathrm{C}$, the $\mathrm{APrBL}$ retains $76 \%$ of the residual activity at this temperature.

The APrBL is stable in the range of $40^{\circ} \mathrm{C}-80^{\circ} \mathrm{C}$ (Figure $4 \mathrm{C}$ ). The protease was highly stable at $40^{\circ} \mathrm{C}$ even after $20 \mathrm{~h}$. While at $50^{\circ} \mathrm{C}$, it was highly stable up to $1 \mathrm{~h}$, the enzyme retained 72 and $62 \%$ of the residual activities after 3 and $20 \mathrm{~h}$ of incubation, respectively. At 60 and $80^{\circ} \mathrm{C}, 85$ and $73 \%$ of the residual activities were evident up to $3 \mathrm{~h}$, respectively, whereas $40 \%$ of the activity was retained at $60^{\circ} \mathrm{C}$, and total loss of the activity was observed at $80^{\circ} \mathrm{C}$ after $3 \mathrm{~h}$ of incubation (Figure $4 \mathrm{C}$ ). The stability profile of APrBL suggests its superiority when compared to other alkaline proteases (Haddar et al., 2009; Jellouli et al., 2011; Cheng et al., 2015).

\section{Effect of Metal lons, Surfactants, Inhibitors, and Solvents}

Among the cations, while $\mathrm{Ca}^{2+}$ slightly stimulated the APrBL activity, $\mathrm{Hg}^{2+}$ completely inhibited the activity (Table 3 ). The trends corresponded with some earlier reports on alkaline proteases (Patel et al., 2006; Cheng et al., 2015). $\mathrm{Hg}^{2+}$ reacts with the aromatic ring of tryptophan oxidizing its indole ring (Liu et al., 2010). APrBL activity was marginally inhibited by $\mathrm{Mg}^{2+}, \mathrm{Mn}^{2+}, \mathrm{Zn}^{2+}$, and $\mathrm{Co}^{2+}$, while $\mathrm{Fe}^{2+}$ significantly reduced the activity by $60 \%$ (Table 3 ). In a similar manner, an alkaline protease from $B$. halotolerans 


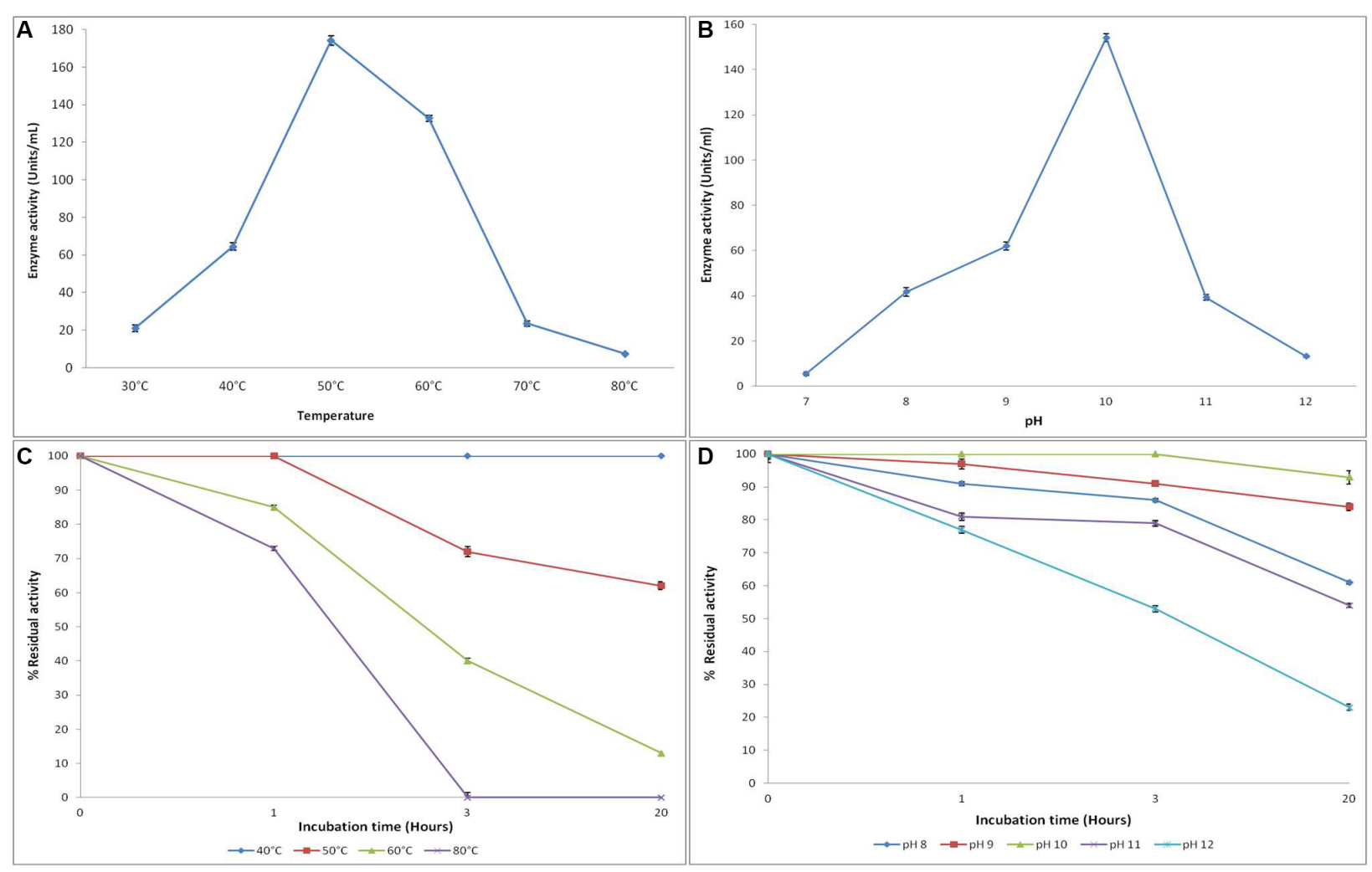

FIGURE 4 | Effect of temperature and pH on the activity $(\mathbf{A}, \mathbf{B})$ and stability $(\mathbf{C}, \mathbf{D})$ of recombinant alkaline protease APrBL, respectively.

was marginally inhibited by $\mathrm{Mg}^{2+}, \mathrm{Zn}^{2+}$, and $\mathrm{Co}^{2+}$ while strongly inhibited by $\mathrm{Fe}^{2+}$ (Dorra et al., 2018). In comparison, $\mathrm{Zn}^{2+}$ inhibited the activity by $50 \%$, while $\mathrm{Fe}^{2+}$ marginally inhibited the activity (Devi et al., 2016). Majority of the proteases of Bacillus sp. are induced by $\mathrm{Ca}^{2+}$ (Dodia et al., 2008; Haddar et al., 2009). $\mathrm{Ca}^{2+}$ marginally stimulated the activity of alkaline protease as also reported earlier for serine proteases of Bacillus sp. (Jain et al., 2012). Despite some benefits, calcium dependency raises limitations of using enzymes in detergents containing chelating agents (Sato et al., 1990). Calcium-independent protease variants can be obtained by removing the calcium-binding loop using directed mutagenesis (Strausberg et al., 1995). Therefore, the calciumindependent character of the APrBL adds to its suitability as a detergent additive.

Various inhibitors were assessed for their effect on the protease activity. The activity was completely inhibited by PMSF, suggesting its serine nature (Table 3 ). The essential serine residue in the active site is sulfonated by PMSF, leading to the total loss of the activity (Mechri et al., 2017). Further, APrBL was inhibited by DTT, $\beta$-ME, and EDTA, retaining 37,31 , and $66 \%$ activities, respectively (Table 3 ).

Among the surfactants, SDS stimulated APrBL activity by 2.35-fold (Table 3). Previously, 1.55- and 3.35-fold enhancement in the activity are reported by SDS in Nocardiopsis alba and Bacillus sp. (Gohel and Singh, 2012; Jain et al., 2012). APrBL enzyme was relatively less stable in non-ionic surfactants such as Triton X-100 and Tween-80 as compared to some earlier reported proteases (Annamalai et al., 2014). Recently, a 50\% induction of an alkaline protease activity by SDS was reported (Dorra et al., 2018). However, majority of the serine alkaline protease are reported as SDS labile (Haddar et al., 2009; Jellouli et al., 2011; Raval et al., 2014; Zhang et al., 2016). Due to the amphiphilic nature, SDS reacts with the amino acids, leading to protein unfolding and loss of activity. On the contrary, SDS favorably changes the confirmation of the APrBL protease and stimulates the activity. The recombinant protease might be slightly misfolded yet retains full activity after the interaction with SDS.

The alkaline proteases have a potential role in ester and peptide synthesis under non-aqueous conditions (Jellouli et al., 2011). The advantages of non-aqueous catalysis include the use of water-insoluble substrates, reduced side reactions, reduced microbial contamination, easy product separation and recovery, and thermodynamic equilibrium favoring synthesis (Klibanov, 2001). However, enzymes lose their conformation in organic solvents, leading to the loss of structural flexibility due to the stripping off of the essential water layer (Doukyu and Ogino, 2010). Hence, enzyme activity and stability in organic solvents become major challenge. APrBL activity was significantly enhanced by chloroform and benzene and moderately enhanced by n-butanol and toluene (Table 3). On the contrary, adverse 
TABLE 3 | Effect of various additives on the purified APrBL enzyme activity.

\begin{tabular}{|c|c|}
\hline Additives & Residual activity (\%) \\
\hline \multicolumn{2}{|c|}{ Solvents [10\% (v/v)] } \\
\hline Control & $100 \pm 1$ \\
\hline n-Hexane & $85.39 \pm 3.8$ \\
\hline DMF & $35.35 \pm 3.07$ \\
\hline Propanol & $75.36 \pm 1.55$ \\
\hline Chloroform & $378.51 \pm 1.55$ \\
\hline Glycerol & $22.27 \pm 0.69$ \\
\hline Toluene & $113.07 \pm 0.78$ \\
\hline n-Butanol & $118.2 \pm 2.84$ \\
\hline Benzene & $146.95 \pm 3.89$ \\
\hline Methanol & $76.15 \pm 0.79$ \\
\hline Ethanol & $53.83 \pm 1.52$ \\
\hline \multicolumn{2}{|l|}{ Metal ions (5 mM) } \\
\hline Control & $100 \pm 1$ \\
\hline $\mathrm{Ca}^{2+}$ & $107.8 \pm 4.26$ \\
\hline $\mathrm{Mg}^{2+}$ & $77.7 \pm 2.55$ \\
\hline $\mathrm{Zn}^{2+}$ & $63.2 \pm 2.55$ \\
\hline $\mathrm{Mn}^{2+}$ & $76.4 \pm 4.24$ \\
\hline $\mathrm{Hg}^{2+}$ & 0 \\
\hline $\mathrm{Co}^{2+}$ & $84.3 \pm 1.70$ \\
\hline $\mathrm{Fe}^{2+}$ & $38.5 \pm 3.40$ \\
\hline \multicolumn{2}{|c|}{ Surfactants/inhibitors } \\
\hline Control & $100 \pm 1$ \\
\hline EDTA (5 mM) & $46.15 \pm 2.17$ \\
\hline PMSF (5 mM) & 0 \\
\hline DTT (5 mM) & $36.92 \pm 4.35$ \\
\hline$\beta-\mathrm{ME}(5 \mathrm{mM})$ & $30.765 \pm 2.17$ \\
\hline SDS [1\% (w/v)] & $275.38 \pm 4.35$ \\
\hline Triton X-100 (1\%) & $36.92 \pm 2.17$ \\
\hline Tween 80 [1\% (v/v)] & $54.61 \pm 5.44$ \\
\hline
\end{tabular}

effect on the activity of alkaline protease by benzene and toluene has been reported earlier (Joshi and Satyanarayana, 2013). Further, methanol, ethanol, and isopropanol positively affected the APrBL activity, as against the toluene and hexane, which considerably acted against the enzyme (Devi et al., 2016). In the present study, dimethylformamide (DMF) and glycerol significantly inhibited the APrBL activity, while the activity was moderately inhibited by $\mathrm{n}$-hexane, propanol, methanol, and ethanol (Table 3). There are several studies on the stimulation of protease activity by methanol and ethanol (Thumar and Singh, 2009; Sinha and Khare, 2014; Mechri et al., 2017). APrBL enzyme was studied in a broad range of organic solvents of variable $\log P$-value ( -2.32 to 3.9$)$. Solvents with $\log \mathrm{P}<4.0$ are considered as extremely toxic due to their greater partitioning into the aqueous and hydrophobic layers (Mechri et al., 2017). Thus, due to the disruption of the hydrogen bonds and hydrophobic interactions depriving the water hydration shell of the protein, the structural flexibility and functionality are lost (Barberis et al., 2006; Mechri et al., 2017). The haloalkaliphilic bacteria decrease the water activity in the cytoplasm by accumulating salt and thus mimic a non-aqueous system. The enzymes by adapting to high salt are able to function in non-aqueous media. The APrBL was stable in all solvents except those of $\log P<0.24$, which might be due to a larger number of acidic amino acids on its surface as evident from its structure (Table 1). The negative charges enhance protein solubility through hydrated ion network with cations or by preventing the protein aggregation via electrostatic repulsion on the protein surface (Jain et al., 2012). The experiments were carried out in triplicates, and the results are presented as the mean values.

\section{Structure-Function Analysis of APrBL}

The physicochemical properties of APrBL elucidated by ProtParam, including the amino acid composition, instability index, theoretical pI, molecular weight, grand average of hydropathicity (GRAVY), aliphatic index, and total number of negatively and positively charged residues, are shown in Table 3. Proteins with an instability index of below 40 are predicted stable, while those with values above 40 are predicted unstable (Guruprasad et al., 1990). Instability index was as low as 26.23, clearly suggesting the stability of the protein. Further, aliphatic index and grand average of hydropathicity (GRAVY) index were 85.44 and -0.036 , respectively. The GRAVY index is the sum of hydropathy values of all the amino acids divided by the number of residues in the sequence. A low GRAVY index of APrBL indicates low hydrophobicity and high hydrophilicity of the protein, suggesting a better interaction with water. The aliphatic index is measured by the relative volume occupied by the aliphatic side chains. It may enhance the thermostability of the globular proteins (Ikai, 1980). A high aliphatic index of the protein indicates its enhanced thermostability over a broad range of temperatures, as reflected by the APrBL and supported by the experimental data. A high number of negatively charged amino acids (Asp + Glu: 30) as compared to positively charged amino acids (Arg + Lys: 14) is believed to confer alkali-halo stability of the protease. The ratio of Asp + Glu/Arg + Lys was found to be 2.14, which is highest for APrBL in comparison with other phylogenetic relatives (Table 1). Normally, in the presence of salt ions, the enzyme gets precipitated. However, with respect to the halophilic enzymes, negative charges stabilize water and/or ion-binding essential for the tertiary or quaternary structure (Takenaka et al., 2011). The negative charges promote protein refolding and prevent aggregation. The APrBL exhibited 8.90\% negatively charged residues, which is higher than other alkaline proteases, M-protease (3.36\%), subtilisin $\mathrm{BPN}^{\prime}(5.08 \%)$, and subtilisin Carlsberg (7.38\%) (Jacobs et al., 1985; Gallagher et al., 1996; Shirai et al., 1997). The features of the primary structure of the APrBL align with some earlier reported proteases: BLAP protease (Joshi and Satyanarayana, 2013), YaB protease (Kaneko et al., 1989), and AprN (Masui et al., 1998) (Table 1). On the contrary, non-halophilic subtilisin Carlsberg and subtilisin BPN' have a reduced number of negatively charged and hydrophobic residues, high number of aromatic amino acids, high GRAVY index, and low aliphatic index. Moreover, APrBL exhibited as high as $55.3 \%$ hydrophobic amino acids which might be responsible for solvent stability (Karan et al., 2011). Solvent stability of the enzyme was also supported by the hydropathy profile of the amino acid sequence of APrBL, which reveals 
A

A

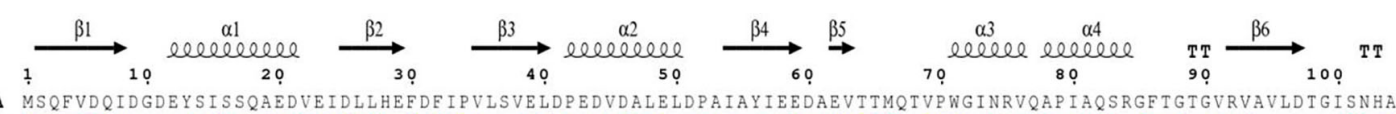

APrBL_A MSQFVDQIDGDEYSTSSQADDVETDOF acc hyd $^{\text {a }}$

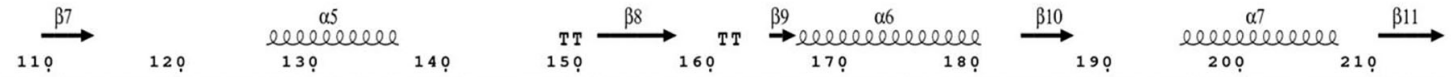

APrBL_A GGASEVPGEPNISDGNGHGTHVAGT IAALNNSIGVLGVAPNVDLYGVKVLGASGSGSISGIAQGLQWAANGMHIANMS LGSSGGATMEQAVNQATASGVLVVAASGN acc
hyd

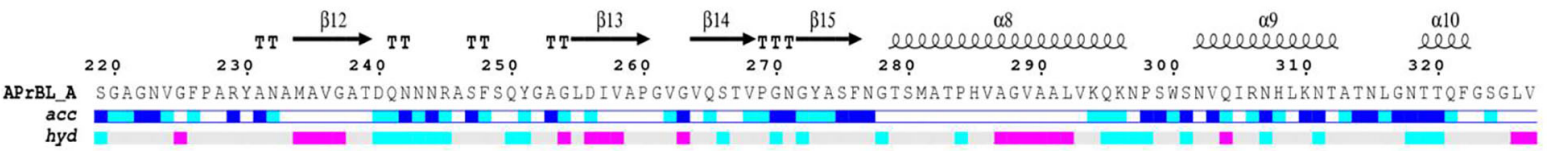

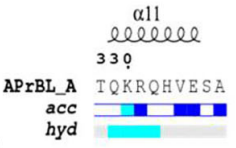
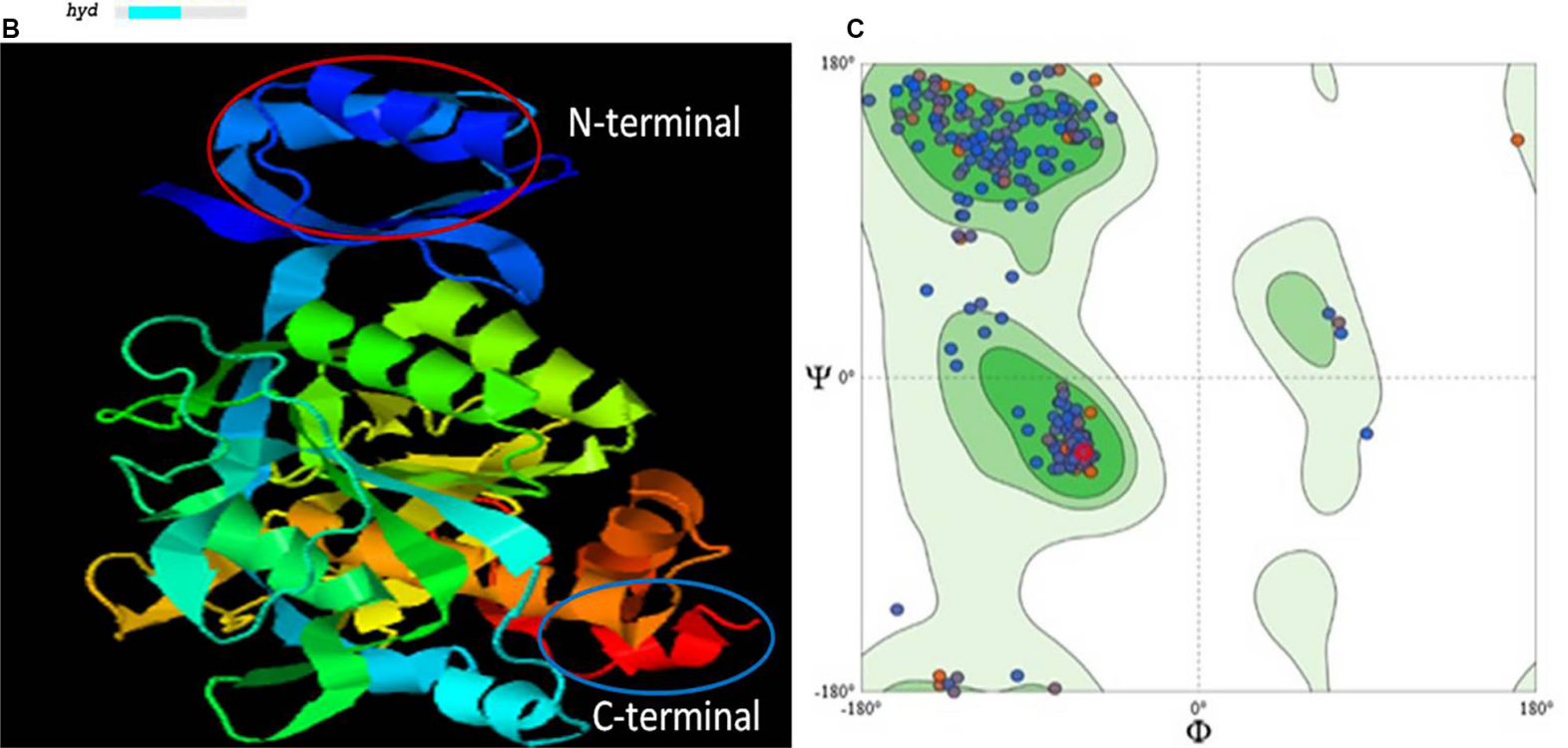

FIGURE 5 | (A) Secondary structure prediction of APrBL by ENDscript 2.0. On the top are secondary structures (squiggles: helices, arrows: beta strands, $\Pi$ letters: beta turns). On the bottom, acc denotes bar of accessibility (dark blue: accessible, light blue: intermediate, white: buried) and hyd denotes a bar of hydropathy (pink: hydrophobic, light blue: hydrophilic, white neutral). (B) Three-dimensional (3D) structure showing N-terminal and C-terminal of APrBL generated using I-TASSER server. (C) Ramachandran plot for the predicted 3D structure of APrBL by SWISS-MODEL. A total of $95.22 \%$ of the residues are distributed in the most favored region which predicts its stability.

hydrophobic nature of the protein (Supplementary Figure S3). Interestingly, although high glycine and less proline content is a characteristic feature of the cold-adapted enzymes, it was observed in thermo active APrBL, which suggests that this feature may not be solely responsible for thermal/cold adaptation.

\section{Secondary and Three-Dimensional Structure Modeling of the APrBL}

Secondary structure of APrBL as analyzed by END script 2.0 indicated $10 \alpha$-helices and $16 \quad \beta$-sheets (Figure 5A). The SOPMA tool revealed that the APrBL contained $31.75 \%$ $\alpha$-helices, $22.55 \% \quad \beta$-strands, and $45.70 \%$ coils, suggesting the dominance of the coils. The halophilic and alkaliphilic enzymes need to maintain a balance between enough rigidity to prevent the unfolding and flexibility to allow the motions necessary for the catalysis (Zorgani et al., 2014). Therefore, the coil regions in APrBL provide a flexible conformation enhancing its activity and stability under the saline and alkaline conditions. On the contrary, non-halophilic enzymes contain more $\alpha$-helix and $\beta$-strand-forming regions (Zorgani et al., 2014). A similar trend was observed in an alkaline protease from B. pumilus (Baweja et al., 2016). Further, low $\mathrm{K}_{\mathrm{m}}$ and high $\mathrm{K}_{\text {cat }}$ values of APrBL could be attributed to the dominance of coils which confers structural flexibility to the enzyme. Structural flexibility in the active site of the enzyme might facilitate efficient substrate binding and catalysis. Nevertheless, stability of APrBL at high temperatures and alkaline $\mathrm{pH}$, solvents, and detergent is presumably due to the 
$\alpha$-helices and $\beta$-strands that provide rigidity to the structure (Fields et al., 2015).

It is hypothesized that a high number of hydrophobic amino acids facilitated APrBL folding in a way to generate more grooves to avoid water molecule. High hydrophobicity in protein promotes stability in stressful conditions. However, the balance of the hydrophobic and hydrophilic regions is important for the interaction of the protein with its surrounding medium, at the same time to increase the substrate binding capacity in the core region required for the efficient catalysis (Panja et al., 2020).

The tertiary structure model was generated by I-TASSER which combines the methods of threading, ab initio modeling, and structural refinement (Figure 5B). The 3D model explained that amino acids forming catalytic triad are in close proximity in tertiary structure but located far apart in primary structure. Therefore, appropriate folding of the enzyme brings amino acids together which are crucial to the catalytic activity in the tertiary structure of the enzyme. The structure had a good $\mathrm{C}$ score of 1.56 (range -5 to 2) and TM score of 0.93 . A TM score of $>0.5$ indicates a model of correct topology. The quality of $3 \mathrm{D}$ structural model was validated by structure analysis tool of SWISS-MODEL. High score value for local quality plot $(>0.6)$ supports the structure of the APrBL as a good feature. In addition, Ramachandran plot indicated that $95.22 \%$ of the amino acid residues are located in the most favored region, which further validates as a good quality model (Figure 5C).

\section{Homology Modeling Analysis of APrBL}

SWISS-MODEL workspace of expasy platform was used to search template for homology modeling. Homology search of APrBL has shown highest structural similarity of $80.97 \%$ with the crystal structure of alkaline M-protease (1wsd.1.A protein) from Bacillus clausii strain KSM-K16 (PubMed ID: 9278275). An alkaline M-protease optimally acts at pH 12.3 (Shirai et al., 1997). In homology modeling, QMEAN, a composite estimator, provides both global (i.e., for the entire structure) and local (i.e., per residue) quality estimates based on the single model (swissmodel.expasy.org). The QMEAN Z-score provides an estimate of the "degree of nativeness" of the structure which indicates whether this model would fit into the experimental structures of similar size (swissmodel.expasy.org). QMEAN $Z$-score near zero suggests correspondence between the model and the experimental structure. Lower scores are indicative of low quality of the model. A QMEAN $Z$-score of -0.12 for the APrBL supports the homology model.

\section{Applications of the Recombinant Alkaline Protease APrBL \\ Wash Performance Analysis of APrBL}

Stain removal ability of the APrBL was analyzed on cotton cloths. The washing test of the APrBL revealed significant removal of bloodstain from the cotton cloth when compared to controls (Figure 6). The washing efficiency of the detergents alone revealed that a complete stain removal with Ariel and Tide, while the detergents Surf, Nirma, and Wheel could not completely remove the stain. However, the stain was completely removed with the supplementation of the APrBL in the detergents
(Figure 6). During the removal of the proteinaceous substrates in the cloths, the proteins are degraded into smaller peptides due to the action of the detergent and/or supplemented proteases. In case of the smaller peptides, they are either solubilized into the washing solution or get deposited back on the fabric. Therefore, the suitable enzymes with improved hydrolysis would aid the stain removal and prevent redeposition. In this investigation, the treatment with APrBL plus detergent not only removed the stain by hydrolyzing the protein but also prevented protein redeposition on the fabric. The application of alkaline proteases in bloodstain removal is described in the literature (Beg and Gupta, 2003; Jaouadi et al., 2008; Patil et al., 2016; Mechri et al., 2017; Rekik et al., 2019). Noticeably, APrBL efficiently removed the bloodstains within $10 \mathrm{~min}$ compared to $30-60 \mathrm{~min}$ by the previously reported proteases (Beg and Gupta, 2003; Jaouadi et al., 2008; Patil et al., 2016; Mechri et al., 2017; Rekik et al., 2019). These findings further add to the potential of APrBL in detergent industry.

\section{Whey Protein Hydrolysis}

Whey, a by-product of the dairy industry, provides important nutritional ingredients (Sinha et al., 2007). The most important proteins in whey are $\alpha$-lactalbumin and $\beta$-lactoglobulin, representing $70-80 \%$ of its total protein content (Smithers et al., 1996). Besides, whey possesses antioxidant properties attributed to high presence of sulfur-containing amino acids. However, due to its high organic content, it is also considered as one of the most polluting agents of water bodies (Moreno-Indias et al., 2009).

Effect of APrBL on whey protein led to a decreased total protein content (Figure 7A). Hydrolysis of the whey protein results into small peptides of varied size and free amino acids. SDS-PAGE profile reveals action of APrBL in the gradual conversion of high-molecular-weight whey proteins into low-molecular-weight smaller peptides (Figure 7C). The protein hydrolysates exhibit antimicrobial, antihypertensive, antioxidant, and lipid-lowering properties (Silvestre et al., 2013). Hydrolyzed whey protein-based formulas are favored for infants intolerant to cow's milk protein (Sinha et al., 2007). In our study, $19 \%$ of the hydrolysis was achieved in $8 \mathrm{~h}$ by $\mathrm{APrBL}$ recombinant protease (Figure $7 \mathbf{B}$ ). In majority of the cases, the $\mathrm{DH}$ for whey proteins varies in the range of 5-23\% (Sinha and Khare, 2014). A 28 and $35 \%$ hydrolysis of whey protein was obtained by free and immobilized protease, respectively (Sinha and Khare, 2014). The protein hydrolysates provide growthsupportive peptides, eliminating the need of expensive nutrients in the growth medium (Pintado et al., 1999). The enzymatic processes provide environment-friendly processing conditions with fewer undesirable effects as compared to other conventional methods.

\section{CONCLUSION}

We successfully cloned an alkaline protease gene (APrBL) from B. lehensis JO-26 and optimally expressed in E. coli BL21 


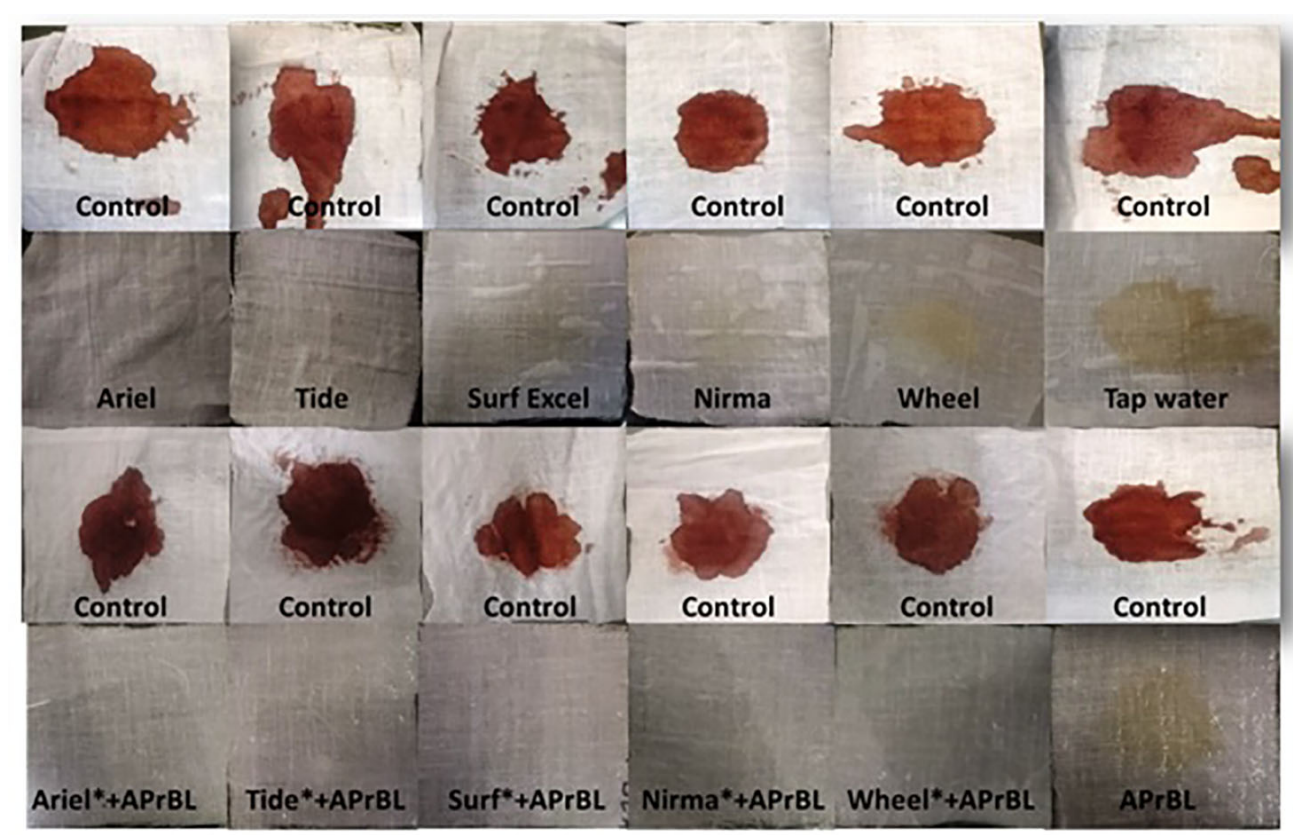

FIGURE 6 | Wash performance analysis showing different washing conditions for bloodstain removal.

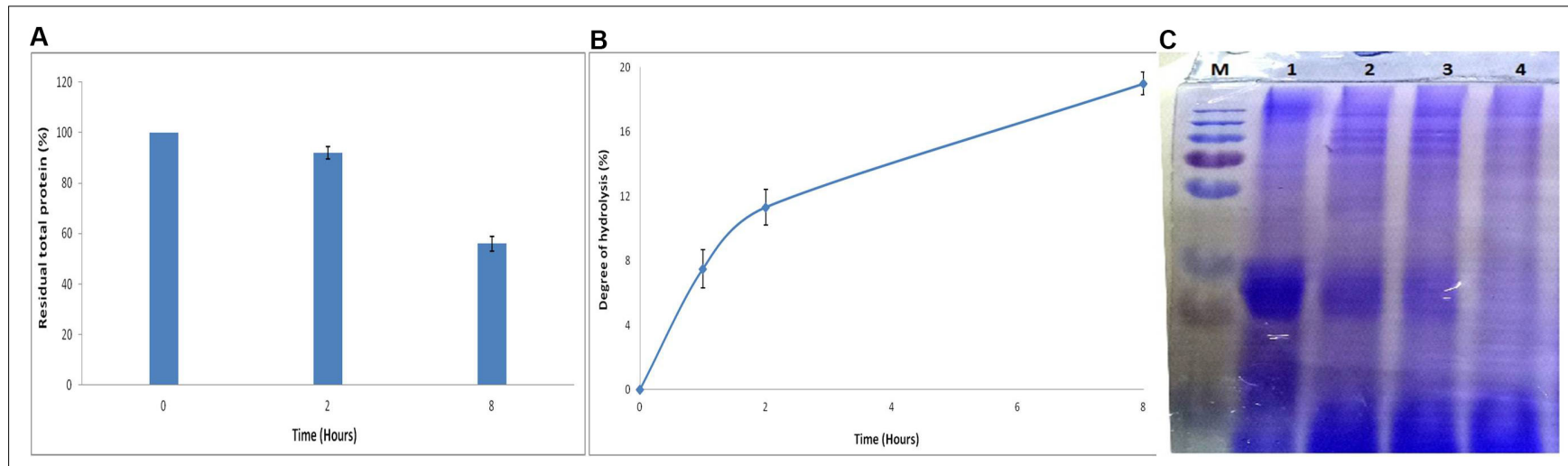

FIGURE 7 | (A) Effect of APrBL enzyme on total protein in milk whey. (B) Effect of APrBL enzyme on degree of hydrolysis of milk whey. (C) Sodium dodecyl sulfate-polyacrylamide gel electrophoresis (SDS-PAGE) profile of untreated and enzymatically hydrolyzed milk whey proteins by APrBL enzyme. M: Marker; Lane 1: untreated whey; Lane 2: treated, 1 h; Lane 3: treated, 2 h; Lane 4: treated, 8 h.

(DE3). The effect of $\mathrm{NaCl}$ on the expression of the alkaline protease was demonstrated. Maximum enzyme expression was achieved with $0.2 \mathrm{mM}$ IPTG, $2 \% \mathrm{NaCl}$ (w/v), and $28^{\circ} \mathrm{C}$ growth temperature. The APrBL has shown high activity and excellent stability over a wide range of $\mathrm{pH}$ and temperatures, with the tolerance against surfactants and reducing agents. Kinetic parameters $K_{\mathrm{m}}, V_{\max }$, and $K_{\text {cat }}$ of the APrBL protease suggest its potential as a biocatalyst. Structural features of APrBL corroborate the experimental data. It was also evident that high glycine and reduced proline content are not solely responsible for the thermal/cold adaptation. The enzyme can also be used in peptide synthesis under non-aqueous environment due to its stability and activity in organic solvents.
Applications of this enzyme as a detergent supplement and in whey protein hydrolysis clearly suggest its suitability in detergent and food industries. We understand this is the first report on the cloning, expression, characterization, and structural elucidation of an alkaline serine protease from a saline desert.

\section{DATA AVAILABILITY STATEMENT}

The alkaline protease gene sequence of Bacillus lehensis JO-26 (APrBL) has been submitted to GenBank (Accession No. MN104891). 


\section{AUTHOR CONTRIBUTIONS}

$\mathrm{HB}$ and SS conceived and designed the experiments. $\mathrm{HB}$ performed the experiments, analyzed data and wrote the manuscript. SS helped in analysis and interpretation of the data. SS supervised the work.

\section{ACKNOWLEDGMENTS}

$\mathrm{HB}$ is thankful to the Council of Scientific and Industrial Research (CSIR), New Delhi, India, for the award of Senior Research Fellowship (CSIR-SRF) and UGC, New Delhi, for

\section{REFERENCES}

Annamalai, N., Rajeswari, M. V., and Balasubramanian, T. (2014). Extraction, purification and application of thermostable and halostable alkaline protease from Bacillus alveayuensis CAS 5 using marine wastes. Food Bioprod Process 92, 335-342. doi: 10.1016/j.fbp.2013.08.009

Armenteros, J. J. A., Tsirigos, K. D., Sønderby, C. K., Petersen, T. N., Winther, O., Brunak, S., et al. (2019). SignalP 5.0 improves signal peptide predictions using deep neural networks. Nat. Biotechnol. 37, 420-423. doi: 10.1038/s41587-0190036-z

Barberis, S., Quiroga, E., Morcelle, S., Priolo, N., and Luco, J. M. (2006). Study of phytoproteases stability in aqueous-organic biphasic systems using linear free energy relationships. J. Mol. Catal. 38, 95-103. doi: 10.1016/j.molcatb.2005.11. 011

Baweja, M., Tiwari, R., Singh, P. K., Nain, L., and Shukla, P. (2016). An alkaline protease from Bacillus pumilus MP 27: functional analysis of its binding model toward its applications as detergent additive. Front. Microbiol. 7:1195. doi: 10.3389/fmicb.2016.01195

Beg, Q. K., and Gupta, R. (2003). Purification and characterization of an oxidationstable, thiol-dependent serine alkaline protease from Bacillus mojavensis. Enzyme Microb. Technol. 32, 294-304. doi: 10.1016/S0141-0229(02)00 293-4

Bhatt, H. B., Begum, M. A., Chintalapati, S., Chintalapati, V. R., and Singh, S. P. (2017). Desertibacillus haloalkaliphilus gen. nov., sp. nov., isolated from a saline desert. Int. J. Syst. Evol. Microbiol. 67, 4435-4442. doi: 10.1099/ijsem.0.002310

Bhatt, H. B., Gohel, S. D., and Singh, S. P. (2018). Phylogeny, novel bacterial lineage and enzymatic potential of haloalkaliphilic bacteria from the saline coastal desert of Little Rann of Kutch, Gujarat, India. 3 Biotech 8:53. doi: 10.1007/ s13205-017-1075-0

Bhatt, H. B., and Singh, S. P. (2016). "Phylogenetic and phenogram based diversity of haloalkaliphilic bacteria from the saline desert," in Microbial Biotechnology, eds B. Bhukya and A. Tangutur (New Jersey: Apple Academic Press), 373-386.

Bradford, M. M. (1976). A rapid and sensitive method for the quantitation of microgram quantities of protein utilizing the principle of protein-dye binding. Anal. Biochem. 72, 248-254. doi: 10.1016/0003-2697(76)90527-3

Briki, S., Hamdi, O., and Landoulsi, A. (2016). Enzymatic dehairing of goat skins using alkaline protease from Bacillus sp. SB12. Protein Exp. Purif. 121, 9-16. doi: 10.1016/j.pep.2015.12.021

Cheng, Q., Xu, F., Hu, N., Liu, X., and Liu, Z. (2015). A novel Ca2+-dependent alkaline serine-protease (Bvsp) from Bacillus sp. with high fibrinolytic activity. J. Mol. Catal. 117, 69-74. doi: 10.1016/j.molcatb.2015.04.006

Contesini, F. J., Melo, R. R. D., and Sato, H. H. (2018). An overview of Bacillus proteases: from production to application. Crit Rev Biotechnol. 38, 321-334. doi: $10.1080 / 07388551.2017 .1354354$

Deng, A., Wu, J., Zhang, G., and Wen, T. (2011). Molecular and structural characterization of a surfactant-stable high-alkaline protease AprB with a novel structural feature unique to subtilisin family. Biochimie 93, 783-791. doi: 10. 1016/j.biochi.2011.01.011

Devi, S. G., Fathima, A. A., Sanitha, M., Iyappan, S., Curtis, W. R., and Ramya, M. (2016). Expression and characterization of alkaline protease from the the award of BSR-Meritorious Fellowship. The authors are grateful to the University Grants Commission (UGC), India, and Saurashtra University for the infrastructural and financial support. Support under the UGC-Centre of Advanced Study, DST-FIST program and DBT-Multi Institutional Project is also acknowledged.

\section{SUPPLEMENTARY MATERIAL}

The Supplementary Material for this article can be found online at: https://www.frontiersin.org/articles/10.3389/fmicb. 2020.00941/full\#supplementary-material

metagenomic library of tannery activated sludge. J. Biosci. Bioeng. 122, 694-700. doi: 10.1016/j.jbiosc.2016.05.012

Dodia, M. S., Bhimani, H. G., Rawal, C. M., Joshi, R. H., and Singh, S. P. (2008). Salt dependent resistance against chemical denaturation of alkaline protease from a newly isolated haloalkaliphilic Bacillus sp. Bioresour. Technol. 99, 6223-6227. doi: 10.1016/j.biortech.2007.12.020

Dorra, G., Ines, K., Imen, B. S., Laurent, C., Sana, A., Olfa, T., et al. (2018). Purification and characterization of a novel high molecular weight alkaline protease produced by an endophytic Bacillus halotolerans strain CT2. Int. J. Biol. Macromol. 111, 342-351. doi: 10.1016/j.ijbiomac.2018.01.024

Doukyu, N., and Ogino, H. (2010). Organic solvent-tolerant enzymes. Biochem. Eng. 48, 270-282. doi: 10.1016/j.bej.2009.09.009

Fields, P. A., Dong, Y., Meng, X., and Somero, G. N. (2015). Adaptations of protein structure and function to temperature: there is more than one way to 'skin a cat'. J. Exp. Biol. 218, 1801-1811. doi: 10.1242/jeb.114298

Gallagher, T., Oliver, J., Bott, R., Betzel, C., and Gilliland, G. L. (1996). Subtilisin BPN'at 1.6 ̊̊ resolution: analysis for discrete disorder and comparison of crystal forms. Acta Cryst. D 52, 1125-1135.

Geourjon, C., and Deleage, G. (1995). SOPMA: significant improvements in protein secondary structure prediction by consensus prediction from multiple alignments. Bioinformatics 11, 681-684. doi: 10.1093/bioinformatics/11.6.681

Gohel, S. D., and Singh, S. P. (2012). Purification strategies, characteristics and thermodynamic analysis of a highly thermostable alkaline protease from a salttolerant alkaliphilic actinomycete. Nocardiopsis alba OK-5. J. Chromatogr. B 889, 61-68. doi: 10.1016/j.jchromb.2012.01.031

Gohel, S. D., and Singh, S. P. (2018). Thermodynamics of a Ca2+ dependent, highly thermostable and detergent compatible purified alkaline serine protease from Nocardiopsis xinjiangensis strain OM-6. Int. J. Biol. Macromol. 113, 565-574. doi: 10.1016/j.ijbiomac.2018.02.157

Gopal, G. J., and Kumar, A. (2013). Strategies for the production of recombinant protein in Escherichia coli. Protein J. 32, 419-425. doi: 10.1007/s10930-0139502-5

Gouet, P., Robert, X., and Courcelle, E. (2003). ESPript/ENDscript: extracting and rendering sequence and $3 \mathrm{D}$ information from atomic structures of proteins. Nucleic Acids Res. 31, 3320-3323. doi: 10.1093/nar/gkg556

Guruprasad, K., Reddy, B. B., and Pandit, M. W. (1990). Correlation between stability of a protein and its dipeptide composition: a novel approach for predicting in vivo stability of a protein from its primary sequence. Protein Eng Des Sel. 4, 155-161.

Haddar, A., Agrebi, R., Bougatef, A., Hmidet, N., Sellami-Kamoun, A., and Nasri, M. (2009). Two detergent stable alkaline serine-proteases from Bacillus mojavensis A21: purification, characterization and potential application as a laundry detergent additive. Bioresour. Technol. 100, 3366-3373. doi: 10.1016/ j.biortech.2009.01.061

Hagihara, B. (1958). The Enzymes, Vol. 4. New York, NY: Academic press Inc.

Haki, G. D., and Rakshit, S. K. (2003). Developments in industrially important thermostable enzymes: a review. Bioresour. Technol. 89, 17-34. doi: 10.1016/ S0960-8524(03)00033-6

Ikai, A. (1980). Thermostability and aliphatic index of globular proteins. J. Biochem. 88, 1895-1898. doi: 10.1093/oxfordjournals.jbchem.a133168 
Jacobs, M., Eliasson, M., Uhlén, M., and Flock, J. I. (1985). Cloning, sequencing and expression of subtilisin Carlsberg from Bacillus licheniformis. Nucleic Acids Res. 13, 8913-8926. doi: 10.1093/nar/13.24.8913

Jain, D., Pancha, I., Mishra, S. K., Shrivastav, A., and Mishra, S. (2012). Purification and characterization of haloalkaline thermoactive, solvent stable and SDSinduced protease from Bacillus sp.: a potential additive for laundry detergents. Bioresour. Technol. 115, 228-236. doi: 10.1016/j.biortech.2011.10.081

Jaouadi, B., Ellouz-Chaabouni, S., Rhimi, M., and Bejar, S. (2008). Biochemical and molecular characterization of a detergent-stable serine alkaline protease from Bacillus pumilus CBS with high catalytic efficiency. Biochimie 90, 1291-1305. doi: 10.1016/j.biochi.2008.03.004

Jellouli, K., Ghorbel-Bellaaj, O., Ayed, H. B., Manni, L., Agrebi, R., and Nasri, M. (2011). Alkaline-protease from Bacillus licheniformis MP1: purification, characterization and potential application as a detergent additive and for shrimp waste deproteinization. Process Biochem. 46, 1248-1256. doi: 10.1016/ j.procbio.2011.02.012

Joshi, S., and Satyanarayana, T. (2013). Characteristics and applications of a recombinant alkaline serine protease from a novel bacterium Bacillus lehensis. Bioresour. Technol. 131, 76-85. doi: 10.1016/j.biortech.2012.12.124

Kaneko, R., Koyama, N., Tsai, Y. C., Juang, R. Y., Yoda, K., and Yamasaki, M. (1989). Molecular cloning of the structural gene for alkaline elastase YaB, a new subtilisin produced by an alkalophilic Bacillus strain. J. Bacteriol. 171, 5232-5236. doi: 10.1128/jb.171.9.5232-5236.1989

Karan, R., Singh, R. K., Kapoor, S., and Khare, S. K. (2011). Gene identification and molecular characterization of solvent stable protease from a moderately haloalkaliphilic bacterium. Geomicrobium sp. EMB2. J. Microbiol. Biotechnol. 21, 129-135. doi: 10.4014/jmb.1007.07064

Kiefer, F., Arnold, K., Künzli, M., Bordoli, L., and Schwede, T. (2009). The SWISSMODEL Repository and associated resources. Nucleic Acids Res. 37(Suppl._1), D387-D392. doi: 10.1093/nar/gkn750

Kimura, M. (1980). A simple method for estimating evolutionary rates of base substitutions through comparative studies of nucleotide sequences. J. Mol. Evol. 16, 111-120. doi: 10.1007/BF01731581

Klibanov, A. M. (2001). Improving enzymes by using them in organic solvents. Nature 409, 241-246. doi: 10.1038/35051719

Kyte, J., and Doolittle, R. F. (1982). A simple method for displaying the hydropathic character of a protein. J. Mol. Biol. 157, 105-132. doi: 10.1016/0022-2836(82) 90515-0

Liu, W., Shi, P., Chen, Q., Yang, P., Wang, G., Wang, Y., et al. (2010). Gene cloning, overexpression, and characterization of a xylanase from Penicillium sp. CGMCC 1669. Appl. Biochem. Biotechnol. 162, 1-12. doi: 10.1007/s12010-0098719-4

Masui, A., Fujiwara, N., Yamamoto, K., Takagi, M., and Imanaka, T. (1998). Rational design for stabilization and optimum $\mathrm{pH}$ shift of serine protease aprN. J. Ferment. Bioengineer. 85, 30-36. doi: 10.1016/S0922-338X(97)80349-2

Maurer, K. H. (2004). Detergent proteases. Curr. Opin. Biotechnol. 15, 330-334. doi: 10.1016/j.copbio.2004.06.005

Mechri, S., Berrouina, M. B. E., Benmrad, M. O., Jaouadi, N. Z., Rekik, H., Moujehed, E., et al. (2017). Characterization of a novel protease from Aeribacillus pallidus strain VP3 with potential biotechnological interest. Int. J. Biol. Macromol. 94, 221-232. doi: 10.1016/j.ijbiomac.2016.09.112

Morais, H. A., Silve, M. P. C., Silva, V. D. M., Silva, M. R., Cristina, A. S., and Silveira, J. N. (2013). Correlation between the degree of hydrolysis and the peptide profile of whey protein concentrate hydrolysates: effect of the enzyme type and reaction time. Am. J. Food Technol. 8, 1-16. doi: 10.3923/ajft.2013.1.16

Moreno-Indias, I., Castro, N., Morales-delaNuez, A., Sánchez-Macías, D., Assunção, P., Capote, J., et al. (2009). Farm and factory production of goat cheese whey results in distinct chemical composition. J. Dairy Sci. 92, 47924796. doi: 10.3168/jds.2009-2215

Panja, A. S., Maiti, S., and Bandyopadhyay, B. (2020). protein stability governed by its structural plasticity is inferred by physicochemical factors and salt bridges. Sci. Rep. 10, 1-9. doi: 10.1038/s41598-020-58825-7

Patel, R. K., Dodia, M. S., Joshi, R. H., and Singh, S. P. (2006). Purification and characterization of alkaline protease from a newly isolated haloalkaliphilic Bacillus sp. Process. Biochem. 41, 2002-2009. doi: 10.1007/s12257-0100410-7

Patil, U., Mokashe, N., and Chaudhari, A. (2016). Detergent-compatible, organic solvent-tolerant alkaline protease from Bacillus circulans MTCC 7942: purification and characterization. Prep Biochem Biotech. 46, 56-64. doi: 10. 1080/10826068.2014.979205

Pintado, M. E., Pintado, A. E., and Malcata, F. X. (1999). Controlled whey protein hydrolysis using two alternative proteases. J. Food Eng. 42, 1-13.

Purohit, M. K., and Singh, S. P. (2013). A metagenomic alkaline protease from saline habitat: cloning, over-expression and functional attributes. Int. J. Biol. Macromol. 53, 138-143. doi: 10.1016/j.ijbiomac.2012.10.032

Purohit, M. K., and Singh, S. P. (2014). Cloning, over expression and functional attributes of serine proteases from Oceanobacillus iheyensis OM A18 and Haloalkaliphilic bacterium OM E12. Process Biochem. 49, 61-68. doi: 10.1016/j. procbio.2013.07.009

Qoura, F., Kassab, E., Reisse, S., Antranikian, G., and Brueck, T. (2015). Characterization of a new, recombinant thermo-active subtilisin-like serine protease derived from Shewanella arctica. J. Mol. Catal. 116, 16-23. doi: 10. 1016/j.molcatb.2015.02.015

Raval, V. H., Bhatt, H. B., and Singh, S. P. (2018). "Adaptation Strategies in Halophilic Bacteria," in Extremophiles, eds C. Gerday and N. Glansdorff (Boca Raton, FL: CRC Press), 137-164.

Raval, V. H., Pillai, S., Rawal, C. M., and Singh, S. P. (2014). Biochemical and structural characterization of a detergent-stable serine alkaline protease from seawater haloalkaliphilic bacteria. Process. Biochem. 49, 955-962. doi: 10.1016/ j.procbio.2014.03.014

Raval, V. H., Rawal, C. M., Pandey, S., Bhatt, H. B., Dahima, B. R., and Singh, S. P. (2015). Cloning, heterologous expression and structural characterization of an alkaline serine protease from sea water haloalkaliphilic bacterium. Ann Microbiol. 65, 371-381. doi: 10.1007/s13213-014-0869-0

Rekik, H., Frikha, F., Jaouadi, N. Z., Gargouri, F., Jmal, N., Bejar, S., et al. (2019). Gene cloning, expression, molecular modeling and docking study of the protease SAPRH from Bacillus safensis strain RH12. Int. J. Biol. Macromol. 125, 876-891. doi: 10.1016/j.ijbiomac.2018.12.103

Rosano, G. L., and Ceccarelli, E. A. (2014). Recombinant protein expression in Escherichia coli: advances and challenges. Front. Microbiol. 5:172. doi: 10.3389/ fmicb.2014.00172

Sato, M., Yoshikawa, K., and Minagawa, M. (1990). The effect of builders on the activity of protease enzymes. J. Am. Oil Chem. Soc. 67, 711-716. doi: 10.1007/ BF02540477

Sharma, A. K., Kikani, B. A., and Singh, S. P. (2020). Biochemical, thermodynamic and structural characteristics of a biotechnologically compatible alkaline protease from a haloalkaliphilic. Nocardiopsis dassonvillei OK-18. Int. J. Biol. Macromol. 153, 680-696. doi: 10.1016/j.ijbiomac.2020.03.006

Shirai, T., Suzuki, A., Yamane, T., Ashida, T., Kobayashi, T., Hitomi, J., et al. (1997). High-resolution crystal structure of M-protease: phylogeny aided analysis of the high-alkaline adaptation mechanism. Protein Eng. 10, 627-634. doi: 10.1093/ protein/10.6.627

Shu, G., Huang, J., Bao, C., Meng, J., Chen, H., and Cao, J. (2018). Effect of different proteases on the degree of hydrolysis and angiotensin I-Converting enzyme-inhibitory activity in goat and cow milk. Biomolecules 8:101. doi: 10 . 3390/biom8040101

Siezen, R. J., and Leunissen, J. A. (1997). Subtilases: the superfamily of subtilisinlike serine proteases. Protein Sci. 6, 501-523. doi: 10.1002/pro.5560060301

Silvestre, M. P. C., Morais, H. A., Silva, V. D. M., and Silva, M. R. (2013). Whey as source of peptides with high antioxidant activity: use of a pancreatin and an Aspergillus sojae protease. Publicatio UEPGCiênc. Biol. Saúde 19, 143-147.

Singh, S. P., Purohit, M. K., Aoyagi, C., Kitaoka, M., and Hayashi, K. (2010). Effect of growth temperature, induction, and molecular chaperones on the solubilization of over-expressed cellobiose phosphorylase from Cellvibrio gilvus under in vivo conditions. Biotechnol. Bioproc. E 15, 273-276. doi: 10.1007/ s12257-009-0023-1

Sinha, R., and Khare, S. K. (2013). Characterization of detergent compatible protease of a halophilic Bacillus sp. EMB9: differential role of metal ions in stability and activity. Bioresour. Technol. 145, 357-361. doi: 10.1016/j.biortech. 2012.11.024

Sinha, R., and Khare, S. K. (2014). Effect of organic solvents on the structure and activity of moderately halophilic Bacillus sp. EMB9 protease. Extremophiles 18 , 1057-1066. doi: 10.1007/s00792-014-0683-4

Sinha, R., and Khare, S. K. (2015). ). Immobilization of halophilic Bacillus sp. EMB9 protease on functionalized silica nanoparticles and application in whey protein hydrolysis. Bioproc. Biosyst. Eng. 38, 739-748. doi: 10.1007/s00449-014-1314-2 
Sinha, R., Radha, C., Prakash, J., and Kaul, P. (2007). Whey protein hydrolysate: functional properties, nutritional quality and utilization in beverage formulation. Food Chemistry 101, 1484-1491.

Smithers, G. W., Ballard, F. J., Copeland, A. D., de Silva, K. J., Dionysius, D. A., Francis, G. L., et al. (1996). New opportunities from the isolation and utilization of whey proteins. J. Dairy Sci. 79, 1454-1459. doi: 10.3168/jds.S0022-0302(96) 76504-9

Sørensen, H. P., and Mortensen, K. K. (2005). Soluble expression of recombinant proteins in the cytoplasm of Escherichia coli. Microb. Cell Fac. 4:1. doi: 10.1186/ 1475-2859-4- 1

Strausberg, S. L., Alexander, P. A., Gallagher, D. T., Gilliland, G. L., Barnett, B. L., and Bryan, P. N. (1995). Directed evolution of a subtilisin with calciumindependent stability. Bio Technol. 13, 669-673. doi: 10.1038/nbt0795-669

Takenaka, S., Yoshida, N., Yoshida, K. I., Murakami, S., and Aoki, K. (2011). Molecular cloning and sequence analysis of two distinct halotolerant extracellular proteases from Bacillus subtilis FP-133. Biosci. Biotechnol. Biochem. 75, 148-151. doi: 10.1271/bbb.100588

Tamura, K., Stecher, G., Peterson, D., Filipski, A., and Kumar, S. (2013). MEGA6: molecular evolutionary genetics analysis version 6.0. Mol. Biol. Evol. 30, 27252729. doi: $10.1093 / \mathrm{molbev} / \mathrm{mst} 197$

Tavano, O. L. (2013). Protein hydrolysis using proteases: an important tool for food biotechnology. J. Mol. Catal. B Enzymatic 90, 1-11. doi: 10.1016/j.molcatb.2013. 01.011

Thakrar, F. J., and Singh, S. P. (2019). Catalytic, thermodynamic and structural properties of an immobilized and highly thermostable alkaline protease from a haloalkaliphilic actinobacteria. Nocardiopsis alba TATA-5. Bioresour. Technol. 278, 150-158. doi: 10.1016/j.biortech.2019.01.058

Thumar, J. T., and Singh, S. P. (2009). Organic solvent tolerance of an alkaline protease from salt-tolerant alkaliphilic Streptomyces clavuligerus strain Mit-1. J. Ind. Microbiol. Biot. 36:211. doi: 10.1007/s10295-008-0487-6
Van Kampen, V., and Merget, R. (2002). Berufliche Atemwegssensibilisierungen durch Subtilisine. Pneumologie 56, 182-186. doi: 10.1055/s-2002-20552

Walstra, P., and Jenness, R. (1984). Dairy Chemistry \& Physics. Hoboken, NJ: John Wiley \& Sons.

Yang, J., Yan, R., Roy, A., Xu, D., Poisson, J., and Zhang, Y. (2015). The I-TASSER Suite: protein structure and function prediction. Nat. Methods 12, 7-8. doi: 10.1038/nmeth.3213

Zhang, H., Mu, H., Mo, Q., Sun, T., Liu, Y., Xu, M., et al. (2016). Gene cloning, expression and characterization of a novel cold-adapted protease from Planococcus sp. J. Mol. Catal. 130, 1-8. doi: 10.1016/j.molcatb.2016. 04.002

Zhou, C., Qin, H., Chen, X., Zhang, Y., Xue, Y., and Ma, Y. (2018). A novel alkaline protease from alkaliphilic Idiomarina sp. C9-1 with potential application for eco-friendly enzymatic dehairing in the leather industry. Sci. Rep. 8, 1-18. doi: 10.1038/s41598-018-34416-5

Zorgani, M. A., Patron, K., and Desvaux, M. (2014). New insight in the structural features of haloadaptation in $\alpha$-amylases from halophilic Archaea following homology modeling strategy: folded and stable conformation maintained through low hydrophobicity and highly negative charged surface. J. Comput. Aided Mol. Des. 28, 721-734. doi: 10.1007/s10822-014-9754-y

Conflict of Interest: The authors declare that the research was conducted in the absence of any commercial or financial relationships that could be construed as a potential conflict of interest.

Copyright (c) 2020 Bhatt and Singh. This is an open-access article distributed under the terms of the Creative Commons Attribution License (CC BY). The use, distribution or reproduction in other forums is permitted, provided the original author(s) and the copyright owner(s) are credited and that the original publication in this journal is cited, in accordance with accepted academic practice. No use, distribution or reproduction is permitted which does not comply with these terms. 